\title{
Influence of Teleconnections on the Precipitation
}

\author{
Engr. Erum Aamir ${ }^{1,2}$ \\ 1 Erum21@hotmail.com (corresponding author) \\ ${ }^{1}$ PhD Scholar Civil Engineering Department, CUST, Islamabad, Pakistan \\ 2 Assistant Professor, National University of Science And Technology ,NUST, Islamabad,Pakistan
}

\begin{abstract}
Precipitation plays vital role in the economy of agricultural country like Pakistan. Baluchistan being the largest province of Pakistan in term of land is facing reoccurring droughts as well as flashflood due unprecedent torrential precipitation pattern. It is quite intriguing to observe the changing pattern of precipitation in Baluchistan. Precipitation has become less frequent but intense in nature which results in flash flooding, landslides, damages to the infra-structure, trade, environment, and ecosystem. Decrease in precipitation are leading to droughts, crop destruction and food scarcity. The assessment of variability in the precipitation trend in Baluchistan is of paramount importance because among all the provinces, Baluchistan is the worst hit, it's under drought warning by Pakistan metrological department (PMD) and already facing water crisis. No substantive studies have been carried out in analyzing the trends in precipitation in Baluchistan. This situation might put China-Pakistan Economic Corridor (CPEC) at risk also. This study is performed on monthly precipitation time series from PMD for determining trends in precipitation on 41 years data from 1977 to 2017 over 13 selected stations in Baluchistan. Due to the non-linear nature of the precipitation data, non-parametric Mann-Kendall (MK) test was used to determine the increasing or decreasing trends in precipitations on monthly basis. Large scale atmospheric circulations and climate indices that affect precipitation were considered to determine their influence on precipitation. The linear association between the climatic indices and Global Precipitation climatology Project (GPCP) precipitation in the monthly time series is determined using Pearson's Correlation. The Partial Mann Kendall test was used to determine the variation in the trend under the influence of climate indices. This study shows that decreasing trends in precipitation are more pronounced rather than the increasing trends and this variation in trends have been explained by the moderate to the strong influence of climate indices on precipitation trends in Baluchistan.
\end{abstract}

\section{KEYWORDS}

Teleconnections, Precipitation, Mann Kendall, Partial Mann Kendall, Climate Indices, Trends

\section{Introduction}

Atmospheric linkage like climate indices strongly control the precipitation and droughts around the world. All around the globe, these climate indices/teleconnections are influencing far-flung as well as nearby regions predominantly through large scale, Qausi stationary atmospheric Rossby waves, consequent of which some regions receive more rainfall or are hotter than the prevailing global scale changes (IPCC.2014). Climate variations are mainly due to large scale ocean circulations, atmospheric circulations, moisture transportation, wind speed, wind direction and heat fluxes etc. Large scale ocean circulations are studied under the influence of teleconnections (Wallace and Gutzler 1981), which reflects our climate pattern (Lucas et al. 2011; Vermeer and Rahmstorf, 2009). Analysis of teleconnections its impact and influence can help apprehend climate and precipitation pattern (Krichak et al. 2014). Pakistan, Indian and China have experienced erratic flash flooding in past few decades due to unprecedented torrential precipitation, (Viterbo et al. 2016; IPCC 2014; Hussain MS, Lee S (2013;2014) Wang et al. 2011; Webster et al. 2011). Robust analysis of unpredicted precipitation is very important to figure out major issues, such as, flooding, landslides, crop destruction, property damage, Losses to the infra-structure, trade, communication, environment, economy and ecosystem, etc. (Bastiaanssen and Ali 2003).

This study is eminent for Pakistan because it is ranked 8th most affected country from 1998 to 2017 by Climate Risk Index (GCRI 2019), having the death toll of 512 people, with total the loss of US\$ 3.8 Billion and the total 145 number of events that struck Pakistan in ten years 1998-2017 (GCRI 2019). Pakistan was also ranked as the third most affected country in 2012 by the impact of climate change (Kreft and Eckstein 2013). According to United Nations Development Program me (UNDP) and the Pakistan Council of Research in Water Resources (PCRWR) reports that by 2025 Pakistan will be water scare country 
from water stressed country if it does not take serious measure and steps now, the situation gets worsen in Baluchistan - the study area in particular due to the fact that water is even now scarce in the area and precipitation which is the main source of water is decreasing. Baluchistan also suffers from devastating, sporadical, catastrophic flash flood due to unprecedented precipitation. Additionally, the contemporary significance of the region is far more than ever before due to China-Pakistan Economic Corridor (CPEC) stretching throughout the province and due to Gawadar port. Moreover, this study would be useful for policy makers to comprehend the latest situation in view of climate change and make policies accordingly (IPCC, 2013).

Teleconnections indices are employed to study climate variability on monthly, seasonal, as well as large time periods. Arctic Oscillation (AO), Indian Ocean Dipole (IOD), El Niño Southern Oscillation (ENSO), North Atlantic Oscillation (NAO), Atlantic Multi-decadal Oscillation (AMO), Quasi-Biennial Oscillation (QBO) and Pacific Decadal Oscillation (PDO) are commonly used circulation indices to assess precipitation variability over Pakistan. Liu D., et al. 2012; Athar H., 2015; Wu et al. 2013 conducted research to study precipitation variation linked with large scale atmospheric and ocean circulation indices on South Asian region. Nevertheless, fewer studies have been undertaken to analyze precipitation variation linked with large scale atmospheric and ocean circulation indices regarding Pakistan, which is among the most vulnerable country according to Global Climate Risk Index (Krishnamurthy and Krishnamurthy (2017); Liess and Geller (2012).

Iqbal and Athar. (2017) uses Pearson's correlation to determine the influence of climatic indices, namely NAO, AO, AMO, IOD, PDO, QBO and ENSO on precipitation with $80 \%$ and above significance level for the positive and negative phases of the indices separately. It was found out that IOD has a positive correlation for its positive phase, the Positive (Negative) phase of AO shows the correlation and PDO shows positive correlation and ENSO exhibits correlation in Baluchistan monthly.

In this study nonparametric Mann Kendall test is used to assess the monthly precipitation trend. The variation in trend in the presence of climate indices is determined by using Partial Mann Kendall, which is the best one step method that do the adjustment for the covariate and trend detection at the same time.

\section{Study Area}

The Province of Baluchistan is selected as the study area for this research. It is the largest province of Pakistan with an area of 347,190 square kilometers which is nearly $44 \%$ of Pakistan's totals land area and forms the southwestern part of the country as shown in Figure-1(Naz et al. 2020; Ashraf et al. 2017; Shahid et al. 2004). Baluchistan is arid, rugged with both plain and mountainous areas. The climate is hot desert type with extreme heat and cold (Ali et al. 2020; Butt and Iqbal 2009). The main financial, monetary, economic, and commercial source of growth of Baluchistan is its coastline on the Arabian Sea and renewable resources like natural gas, coal, precious stones, gems, zinc, lead, marble, and copper etc. Baluchistan is the area of great importance being part of CPEC nowadays and mainly depends on the sustainable rainwater.

The two important elements which affect the weather of Pakistan are monsoon and the Western Disturbance. Light to moderate precipitation in southern parts of the country while moderate to heavy precipitation with heavy snowfall in the northern parts of the country are caused by Western Disturbances typically occurs in the winter months. Monsoon occurs in summer from June till September in almost whole Pakistan excluding Western Baluchistan, FATA, Chitral and Gilgit-Baltistan. These monsoon rains are rather heavy by nature and can cause significant flooding if they interact with western disturbance in the Northern parts of the country. Tropical Storms usually occurs in pre-monsoon months from late April till June and then from late September till November forms usually and affect the coastal localities. When there is no precipitation then mostly Continental air prevails during that period (Hussain and lee 2014; Hanif et al. 2013; Maida and Ghulam 2011).

The weather of Baluchistan is mainly affected by Western Disturbances in winter and spring months. It is less affected by Monsoon in summers and to some extent with tropical storms in coastal areas in autumn (Naz et al. 2020; Gadiwala et al. 2019; Aamir and Hassan 2018; Ahmed et al. 2015; Ashraf et al. 2015).

\section{Data Collection and Preparation}

\section{Precipitation Data}

Monthly Precipitation data in millimeters, for this research was acquired from Pakistan Meteorological department (PMD). Thirteen stations throughout Baluchistan were carefully chosen based on accuracy, completeness and availability of data for the selected study period of 41 years. Thirteen stations all over Baluchistan are shown in Figure-1. 


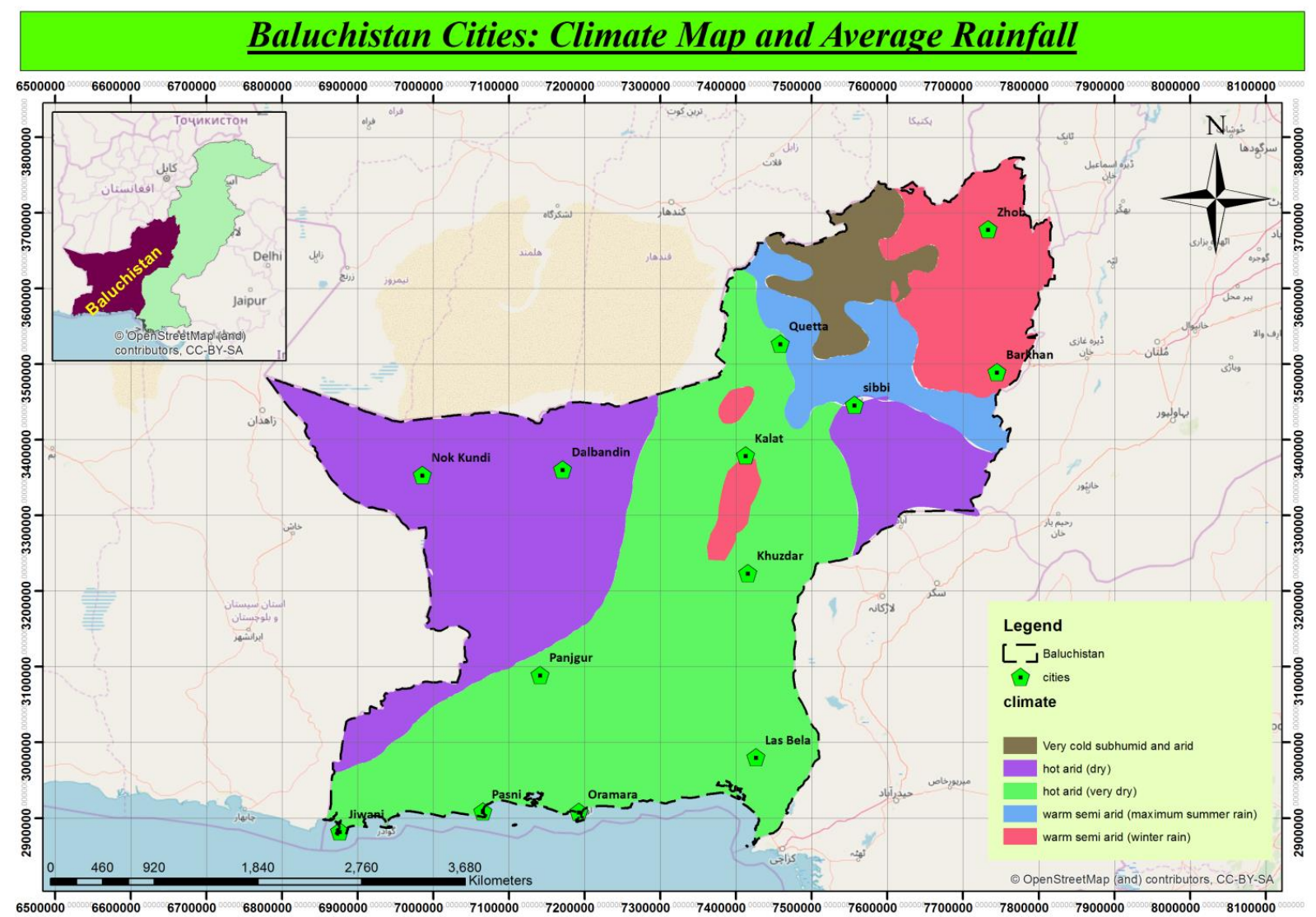

FIGURE 1 The Location Map of Selected PMD Stations in Baluchistan (Figure courtesy of PMD Pakistan).

The Study period constitute of forty-one (41) years from 1977-2017 for the designated 13 different stations in Baluchistan, namely Barakhan, Dalbandin, Jiwani, Kalat, Khuzdar, Lasbella, Nokkundi, Ormara, Pasni, Punjgur, Quetta, Sibbi and Zhob. Data collected from PMD was on the monthly basis in $(\mathrm{mm} / \mathrm{month})$ for each of the weather stations, which were averaged to convert them to annual precipitation data for analysis.

The average rainfall monthly and annually within the study period from 1997-2017 over each of the 13 different stations in Baluchistan is tabulated below in Table-1.

Table-1 Average Precipitation from 1977-2017

\begin{tabular}{|c|c|c|c|c|c|c|c|c|c|c|c|c|}
\hline \multirow{2}{*}{ Stations } & \multicolumn{4}{|c|}{ Winter } & \multicolumn{3}{|c|}{ Spring/Pre-Monsoon } & \multicolumn{3}{|c|}{ Monsoon } & \multicolumn{2}{|c|}{ Post-Monsoon } \\
\hline & Dec & Jan & Feb & Mar & Apr & May & Jun & Jul & Aug & Sep & Oct & Nov \\
\hline Barakhan & 6.5 & 13.1 & 21.1 & 31.3 & 34.6 & 24.7 & 48.2 & 108.4 & 84.6 & 35 & 9.1 & 4.9 \\
\hline Dalbandin & 9.4 & 16.8 & 16 & 20.5 & 4.8 & 1.3 & 3 & 3.7 & 0.7 & 0.1 & 2.2 & 3.1 \\
\hline Jiwani & 20.2 & 22.9 & 22.5 & 14.3 & 3.7 & 0.1 & 7.6 & 3 & 2.3 & 0 & 1.1 & 3.6 \\
\hline Kalat & 30.3 & 34.7 & 37.8 & 31 & 11 & 3.9 & 6.7 & 16.3 & 13.4 & 4.6 & 5 & 5.8 \\
\hline Khuzdar & 14.7 & 16.5 & 30.9 & 29.3 & 16.3 & 14.1 & 16.5 & 51.2 & 56.6 & 9.1 & 6.5 & 4.3 \\
\hline Las bella & 7.3 & 4.8 & 11.4 & 10.4 & 7.4 & 19.7 & 11.2 & 53.2 & 39.3 & 8.6 & 5 & 1.9 \\
\hline Nokkundi & 2 & 7.8 & 9.6 & 8.7 & 2.2 & 0.2 & 2 & 0.7 & 0.3 & 0 & 0.5 & 0.6 \\
\hline Ormara & 11.8 & 10.7 & 10 & 9.9 & 1.6 & 0.2 & 9.7 & 11.3 & 3.8 & 0.3 & 2 & 0.5 \\
\hline Pasni & 19.8 & 22 & 14.9 & 16.4 & 2.3 & 0.5 & 6.7 & 5.2 & 7.7 & 0.5 & 2.3 & 1.7 \\
\hline Punjgur & 10 & 12.8 & 15 & 15.1 & 8.3 & 3.5 & 5 & 12.1 & 7.7 & 1.7 & 2.1 & 1.6 \\
\hline Quetta & 30,8 & 53.8 & 51.7 & 55.5 & 26 & 7.5 & 4 & 12.5 & 11.1 & 3.1 & 5.7 & 8.8 \\
\hline Sibbi & 5.6 & 10.1 & 17.9 & 22.3 & 9.8 & 6 & 15.7 & 38.6 & 39.1 & 12.4 & 3.1 & 1.6 \\
\hline Zhob & 9.2 & 17.1 & 26.9 & 43.5 & 29.1 & 14.8 & 17.7 & 56.2 & 44.8 & 11.1 & 5.8 & 5.6 \\
\hline Monthly & 13.7 & 18.7 & 22.0 & 23.7 & 12.1 & 7.4 & 11.8 & 28.6 & 24.0 & 6.7 & 3.9 & 3.4 \\
\hline
\end{tabular}

Table-1 shows that western parts of Baluchistan such as Dalbandin, Jiwani, Kalat, Nokkundi, Ormara, Panjgur, Pasni, Quetta receives most of its rainfall in Winter Season due to the western disturbance and Eastern parts of Baluchistan such as Barakhan, Khuzdar, Lasbella, Sibbi and Zhob receives its most of the rainfall in Monsoon Season. Stations close to coastal areas also receives scattered rainfall in the post monsoon season when continental air prevails. 
Seven (7) different climatic indices, North Atlantic Oscillation (NAO), Artic Oscillation (AO), Atlantic Multi-decadal Oscillation (AMO), Indian Ocean Dipole (IOD), Quassi Biennial Oscillation (QBO), Pacific Decadal Oscillation (PDO), El Nino Southern Oscillation (ENSO-MEI), known to affect the precipitation in the study area through teleconnections were considered (Athar 2015, Iqbal et al. 2017; Athar 2015; Liu et al. 2012; Afzal et al. 2013). Climatic Indices data and Global Precipitation climatology Project (GPCP) Precipitation on $2.5^{\circ} \times 2.5^{\circ}$ global grid for months from January to December in the Baluchistan is obtained from NOAA/ESRL Physical Science division.

\section{METHODOLOGY}

In the monthly time series precipitation data at each of 13 stations trends are examined using Mann Kendall Tests. The reasons for adopting the Mann Kendall test is that it is strong and insensitive to the data with gaps and best for the data that is not normally distributed, The association between precipitation and climate indices is determined by Pearson's correlation test; whereas the influence of climate indices (influencing variables) on Trends in precipitation is examined by the Partial Mann Kendall test. The tests are performed on individual stations for monthly time series data.

\subsection{Mann Kendall for Trend Detection}

Mann-Kendall (MK) statistical test was largely used in identifying trends in climate variables (Ahmad et al. 2015; Burn and Elnur 2002; Liu, Gao, Chen and Shao 2012; Chaouche, Neppel, Dieulin et al. 2010; Machiwal and Jha 2009; Verwon, Kramer, Becker and Pfister 2008; Yang, Xi, Liu, Li, Hu and Xia 2012; and Scarpati, Spescha, Lay and Capriolo, 2011).

The MK test is a procedure based on ranks and is not sensitive to sudden breaks in the uneven data. The nonparametric MK test is one of the strong methods of identifying monotonic trends in precipitation data where the data is skewed and/or where data is either consistently increasing or decreasing in a time series whereas MK test is not suitable when there are recurring trends.

In MK test, if $(\mathrm{X} 1, \mathrm{X} 2, \ldots . . \mathrm{Xn})$ are a sample of $\mathrm{n}$ independent and identically distributed random variables of the rainfall data, then the Mann-Kendall statistic Sx of the series $x$ is given (Yue. et al. 2002) as:

$$
\begin{gathered}
S=\sum_{i=l}^{n-1} \sum_{j=i+1}^{n} \operatorname{sgn}\left(X_{j}-X_{i}\right) \\
\operatorname{sgn}\left(X_{j}-X_{i}\right)=\left\{\begin{array}{cr}
+1 & \left(X_{j}-X_{i}\right)>0 \\
0 & \text { if }\left(X_{j}-X_{i}\right)=0 \\
-1 & \left(X_{j}-X_{i}\right)<0
\end{array}\right.
\end{gathered}
$$

Where, $i$ and $j$ are the rank of observation of the $x i$ and $x j$ of the time series. The variance associated with Sx is given as

$$
\operatorname{Var}=\frac{n(n-1)(2 n+5)-\sum_{i=1}^{g} t_{i}\left(t_{i}-1\right)\left(2 t_{i}+5\right)}{18}
$$

Where $g$ is the groups of tied rank and $t$ is ties in the group. For a sample size of $n>10$ or larger, the MK statistics $\mathrm{Zmk}$ is computed by

$$
Z_{m k}=\left\{\begin{array}{cl}
\frac{S_{x}-1}{\sigma} & \text { for } S_{x}>0 \\
\frac{S_{x}+1}{\sigma} & \text { for } S_{x}<0 \\
0 & \text { for } S_{x}=0
\end{array}\right.
$$

Positive Zmk values show increasing trends, while negative Zmk values reflect decreasing trends. If $|\mathrm{Zmk}|$ is greater than $\mathrm{Z}$ $1-\alpha / 2$ for the chosen value of significance level, $(\alpha)$ then the trends are considered significant or when $p$-value is smaller than the significance level $(\alpha)$, the null hypothesis (Ho) of no trend is rejected in favor of alternative the hypothesis (Ha) and the trend is considered as a significant trend in the time series. Z 1- $\alpha / 2$ and p-value are obtained from the standard normal distribution table.

\subsection{Pearson's Correlation for Finding Linear Associations}


Based on the method of covariance, Pearson's correlation is one of the best methods that measure the strength of linear association between the two variables. It provides the information about the magnitude and direction of the association. The direction can be positive or negative, and the magnitude ranges between +1 , a perfect positive correlation and -1 , a perfect negative correlation. A value of zero indicates that there is no linear correlation. It should be kept in mind that existence of significant correlation is not causation for the variables. The significance of the correlation is determined by the student $\mathrm{t}$-test. The t-test establishes whether there is an evidence of significant correlation is present between the variables or not. The t-test is given by

$$
\mathrm{t}=\frac{\mathrm{r} * \sqrt{\mathrm{n}-2}}{\sqrt{1-\mathrm{r}^{2}}}
$$

Where, $\mathrm{r}$ and $\mathrm{n}$ are the correlation coefficient and number of observations in the data series respectively. For precipitation and climatic index being the two variables, Correlation is considered significant for the desired value of significance level $(\alpha)$ having $n-2$ degree of freedom if $|t|$ is greater than the critical $t 1-\alpha / 2$ or if $p$-value is smaller than the significance level $(\alpha)$. The null hypothesis of no correlation is rejected in favor of the alternative hypothesis that there is a significant correlation between the precipitation and climatic indices. The $\mathrm{t} 1-\alpha / 2$ and $\mathrm{p}$-value are obtained from the student t-distribution table.

\subsection{Partial Mann Kendall for Examining the Influence of Climatic Indices on Precipitation Trends}

The influence of large-scale climatic and atmospheric indices (influencing variables) such as NAO, AO, AMO, IOD, QBO, PDO, ENSO-MEI on the precipitation time series was examined by adopting the partial Mann-Kendall (PMK) test. Libiseller and Grimvall 2002, Van Oldenborgh et al. 2005, Ashok et al. 2007, Hajani.E et al. 2017, Kumar N and Ouarda 2014, also used PMK in their studies.

PMK is one of the best one step procedures that do the adjustment for covariates (influencing variables) and trend testing simultaneously. In PMK, the effect of explanatory variables is studied on the response variable and the influence is calculated using the conditional mean and the conditional variance of the response variable. As given by Libiseller and Grimvall (2002), the test statistic for response variable $\mathrm{y}$, with its covariate $\mathrm{x}$ being the explanatory variable is given by

$$
P M K=\frac{S_{y}-\hat{\rho} S_{x}}{\sqrt{(1-\hat{\rho}) n(n-1)(2 n+5) / 18}}
$$

Where, Sy is the Mann Kendall statistics of response variable, Sx is the Mann Kendall statistics of explanatory variable, $\rho^{\wedge}$ denotes the conditional correlation between the MK statistics Sx and Sy. The PMK statistic is normally distributed with mean 0 and standard deviation 1. The details can be seen in Libiseller and Grimvall, 2002, studies.

\section{Results and Discussions}

Increasing or decreasing Trends were observed, when the uni-variate Mann Kendall test was run on the precipitation time series data. The effect of Climatic Indices as relevant covariates (influencing variables) was considered to assess the trends in precipitation by applying Partial Mann Kendall.

\subsection{Trends in Precipitations}

Monotonic Trends in precipitation from 1977 to 2017 at 13 stations of Baluchistan is found through Mann Kendall tests monthly at individual stations. Table- 2 shows that out of 15 statistically significant trends, 10 were decreasing trends whereas 5 were increasing trends, which clearly shows that decreasing trend is dominating in most of the stations in Baluchistan which explained the decreasing rainfall prevailing in Baluchistan during the last couple of decades. Kalat, Lasbella, Nokkundi and Pasni showed no statistically significant trend in precipitation at 5\% significance level. Barakhan showed decreasing trend in the month of January and November, Dalbandin, Jiwani and Khuzdar showed decreasing trends in December, Ormara showed decreasing trends in May, Panjgur showed decreasing trends in July and December, Quetta and Zhob showed decreasing trends in January. Barakhan showed the increasing trend in the month of June, Ormara showed increasing trends in May and October, Quetta showed increasing trends in June and September whereas Sibbi showed increasing trends in June.

TABLE 2

MONTHLY SIGNIFICANT INCREASING (DECREASING)

\begin{tabular}{|c|c|c|c|c|c|c|c|c|}
\hline Stations & $\begin{array}{l}\text { Jan } \\
\end{array}$ & May & Jun & $\begin{array}{l}\text { Jul } \\
\end{array}$ & Sep & Oct & Nov & $\overline{D e c}$ \\
\hline Barakhan & $\begin{array}{l}(177) \\
4.62 \%\end{array}$ & & $\begin{array}{c}175 \\
4.93 \%\end{array}$ & & & & $\begin{array}{l}(211) \\
1.07 \%\end{array}$ & \\
\hline
\end{tabular}

TRENDS IN PRECIPITATION - INDIVIDUAL STATIONS 


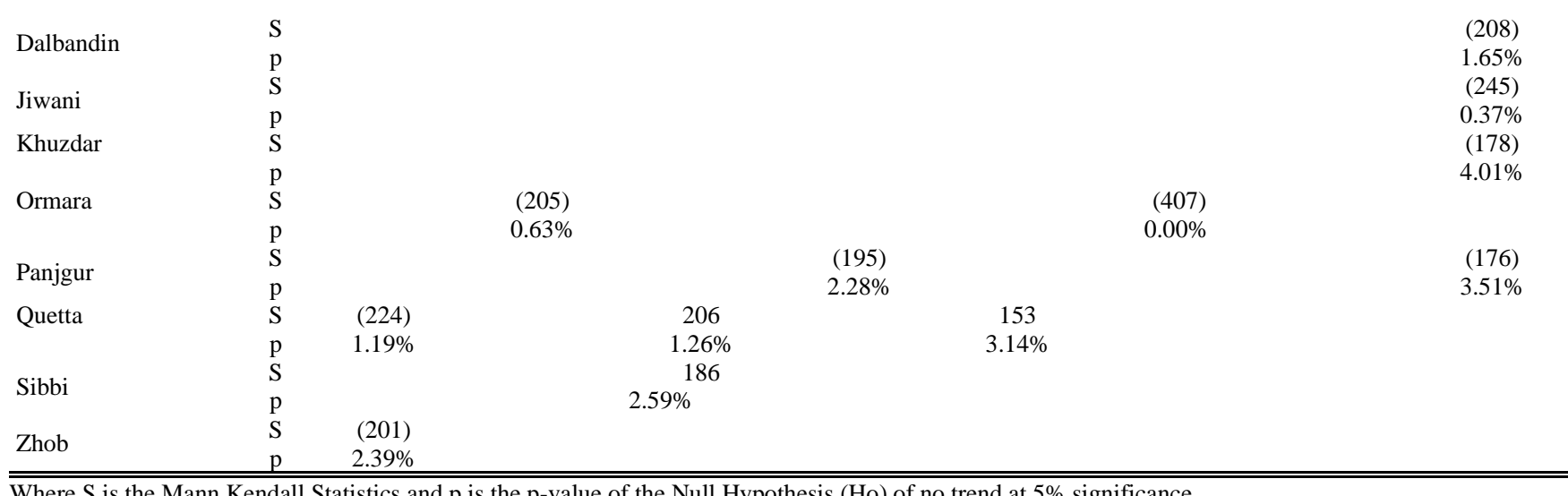

Where $\mathrm{S}$ is the Mann Kendall Statistics and $\mathrm{p}$ is the p-value of the Null Hypothesis (Ho) of no trend at $5 \%$ significance.

\subsection{Linear Association of Climatic Indices with Precipitation}

Pearson correlation is performed between the climate indices and GPCP gridded precipitation to check the association between the two variables. For a 41-year time series data, a correlation value of $0.316(-0.316)$ or higher (lower) is considered significant for a two-tailed test at $5 \%$ significance level.

\subsubsection{Association of NAO with Precipitation}

The correlation contour map of Baluchistan (period 1977 to 2017 and months January to December) between NAO and GPCP for months from January to December in the Baluchistan. The correlation coefficient ranges from -0.4 to 0.4 . The correlation map in Table-3 shows that NAO has a significant negative correlation with October GPCP precipitation.

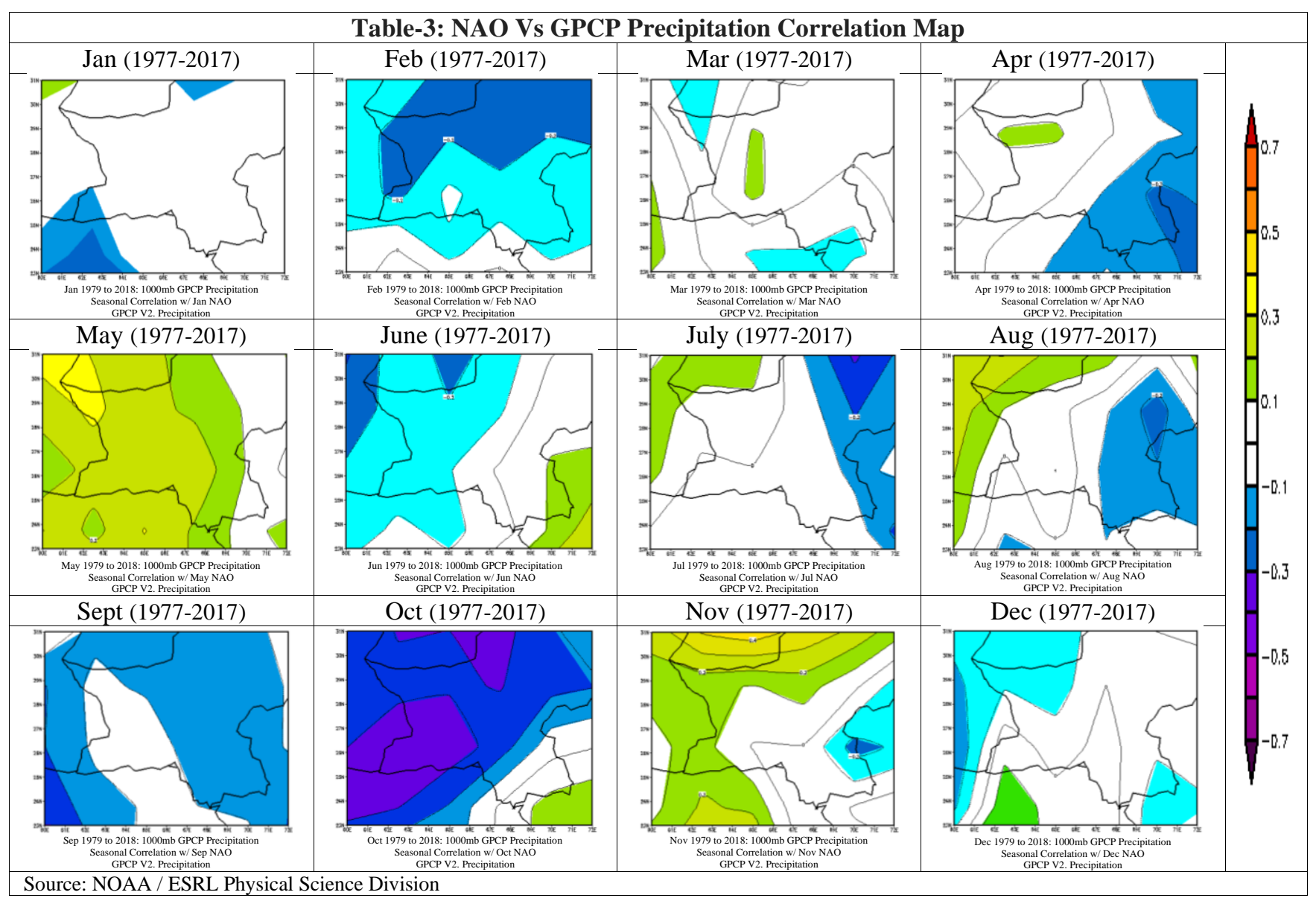

\subsubsection{Association of AO with Precipitation}

The correlation contour map of Baluchistan (period 1977 to 2017 and months January to December) between AO and GPCP Precipitation for months from January to December in the Baluchistan prepared from the NCPP. The correlation coefficient 
ranges from - 0.35 to 0.35 . The correlation map in Table-4 shows that AO has a significant negative correlation with October GPCP precipitation and significant positive correlation with January, November GPCP precipitation.

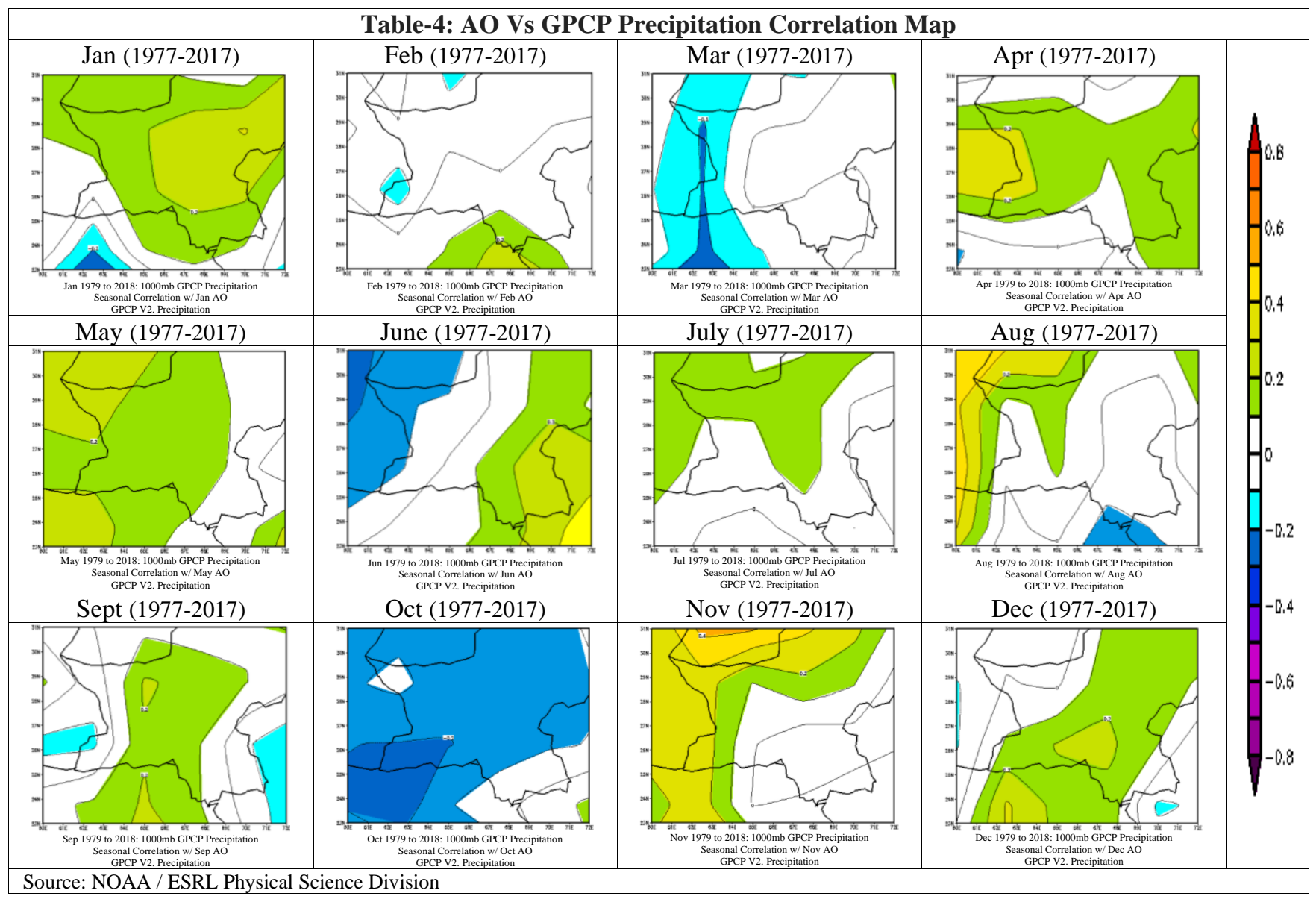

\subsubsection{Atlantic Multi-Decadal Oscillation (AMO)}

The correlation contour map of Baluchistan (period 1977 to 2017 and months January to December) between AMO and GPCP precipitation is attached below. The correlation coefficient ranges from -0.3 to 0.4 . The correlation map in Table- 5 shows that AMO has a significant positive correlation in June and October GPCP precipitation.

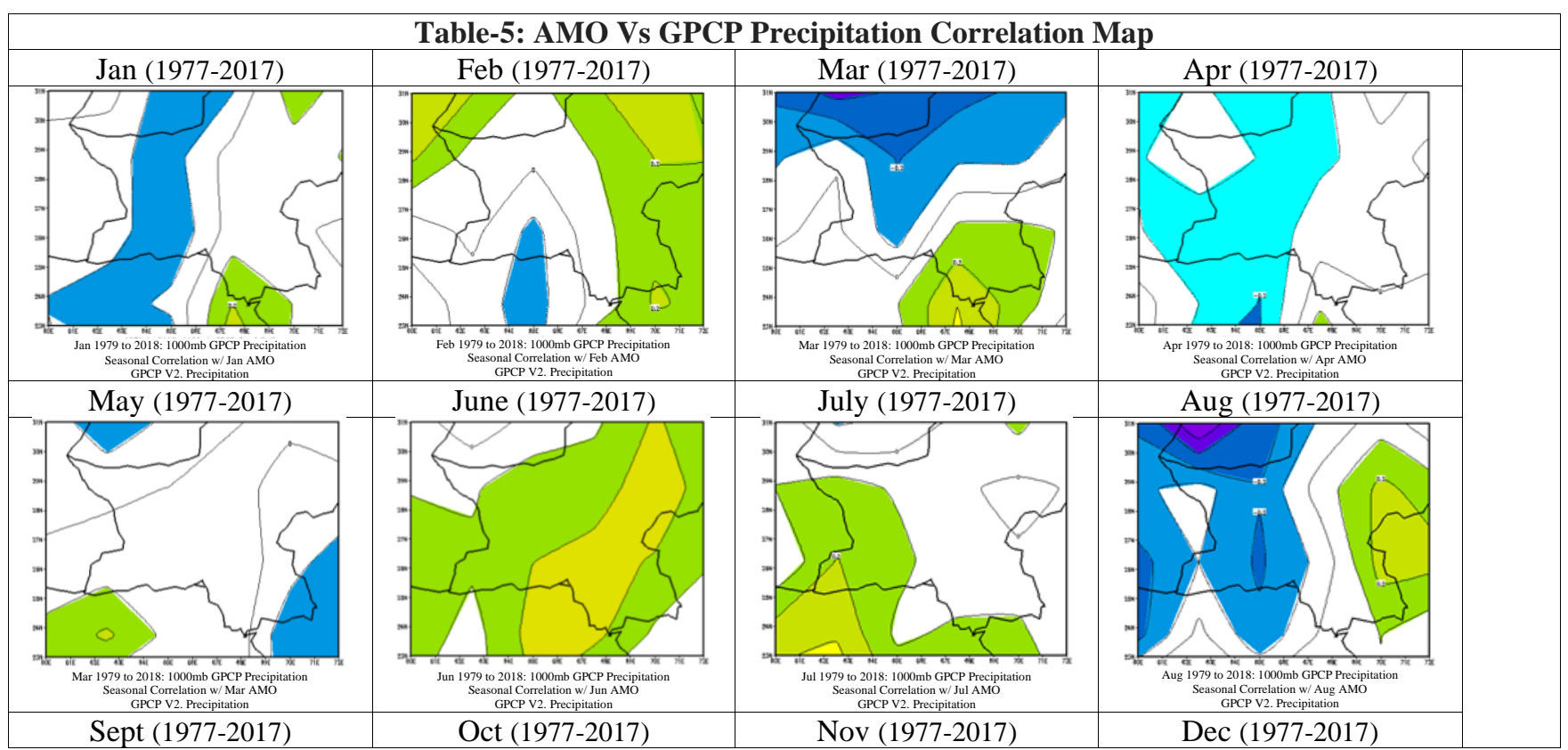




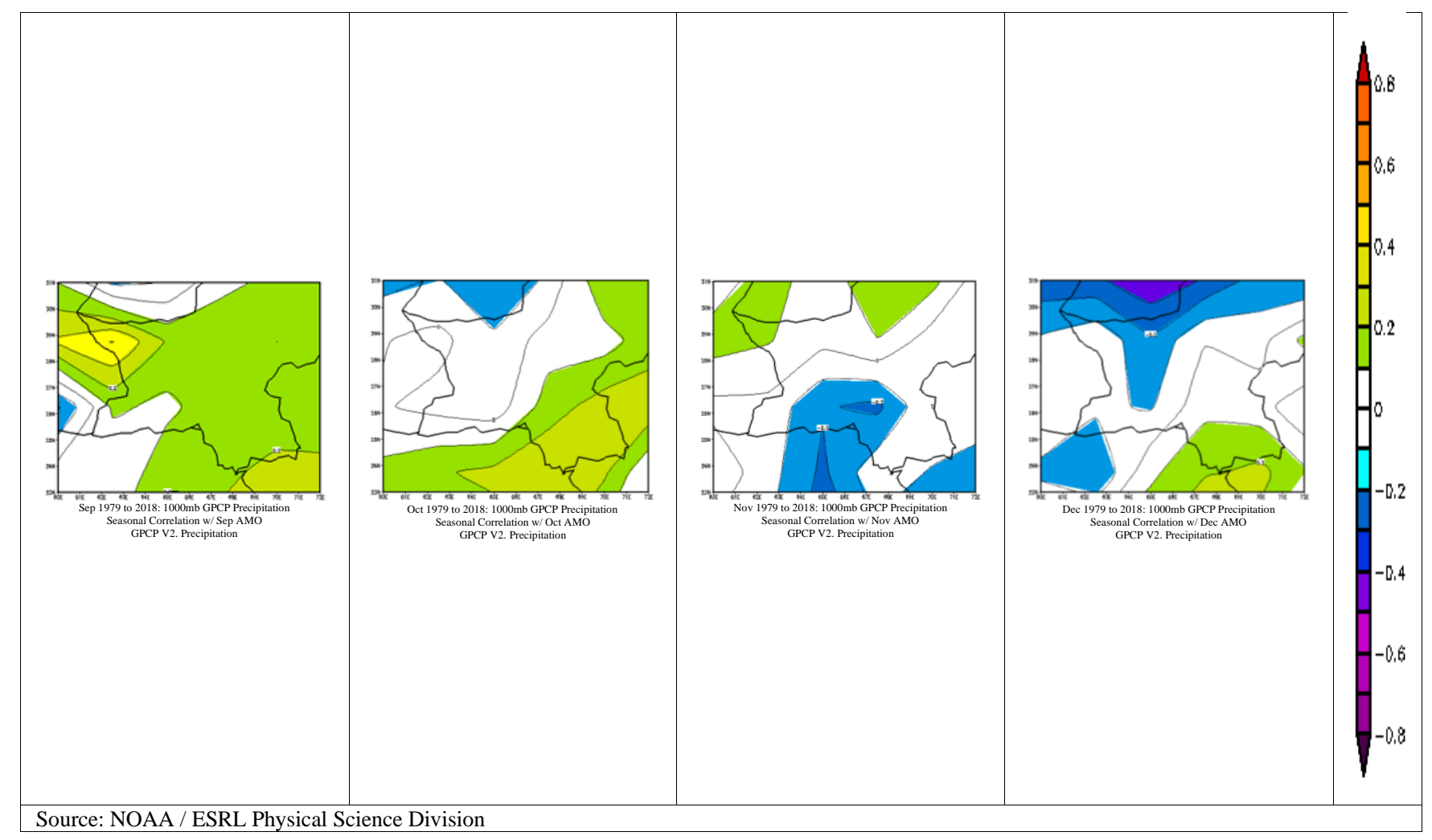

\subsubsection{Association of IOD with Precipitation}

The correlation contour map of Baluchistan (period 1977 to 2017 and months January to December) between IOD and GPCP precipitation is attached below. The correlation coefficient ranges from -0.6 to 0.6. The correlation map in Table- 6 shows that IOD has a negative significant correlation with April GPCP precipitation and the positive significant correlation with May, October, and November GPCP precipitation.

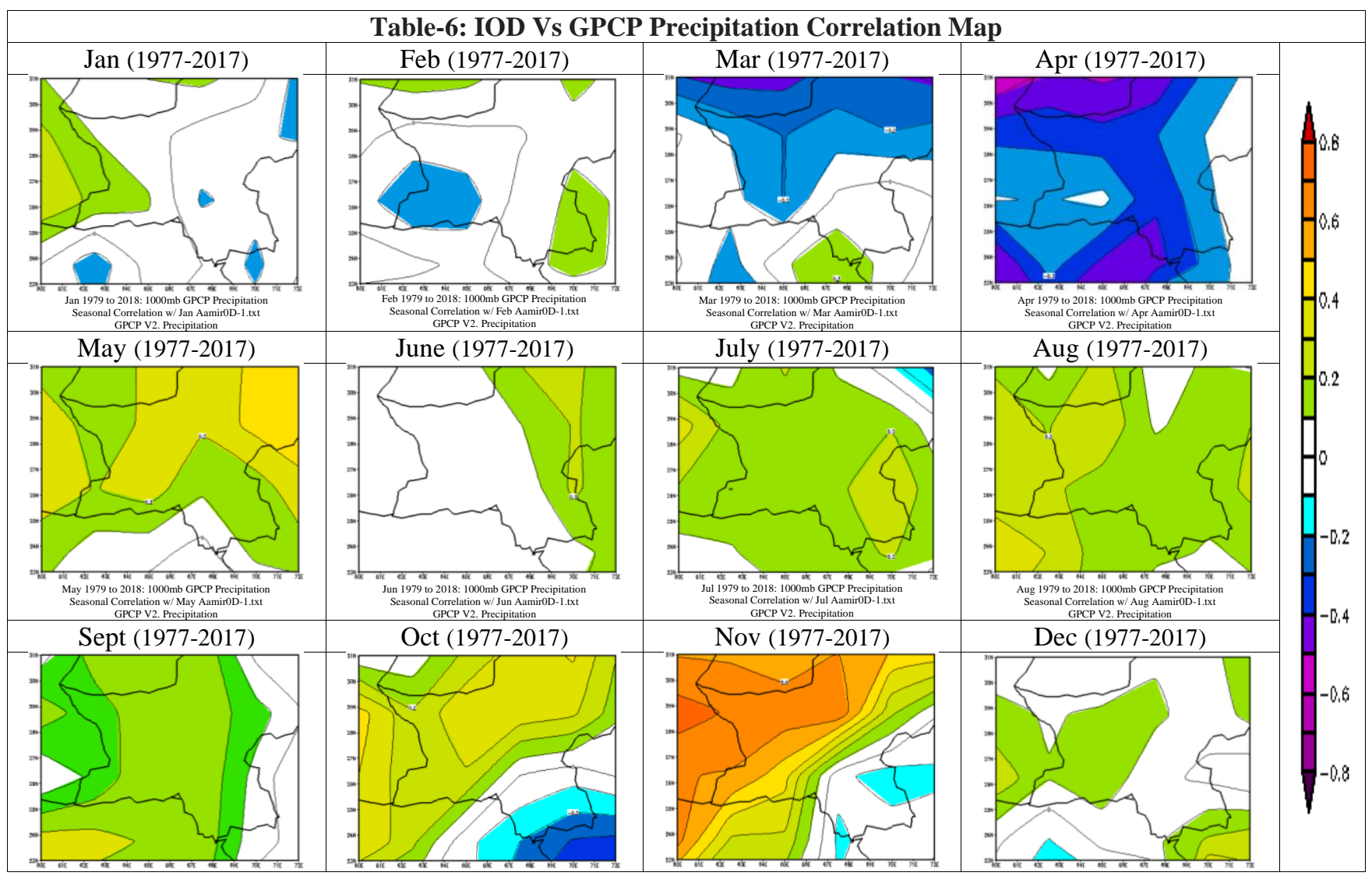




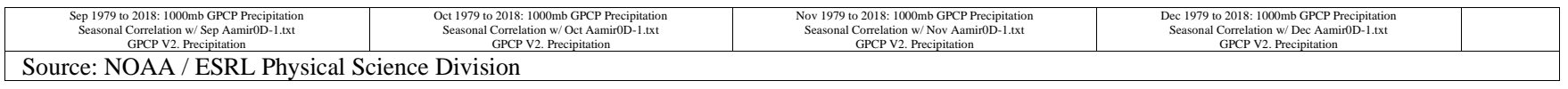

\subsubsection{Association of PDO with Precipitation}

The correlation contour map of Baluchistan (period 1977 to 2017 and months January to December) between PDO and GPCP precipitation is attached below. The correlation coefficient ranges from - 0.6 to 0.5 . The correlation map in Table-7 shows that PDO has a negative significant correlation with January, February, August, September and December GPCP precipitation and the positive significant correlation with October GPCP precipitation

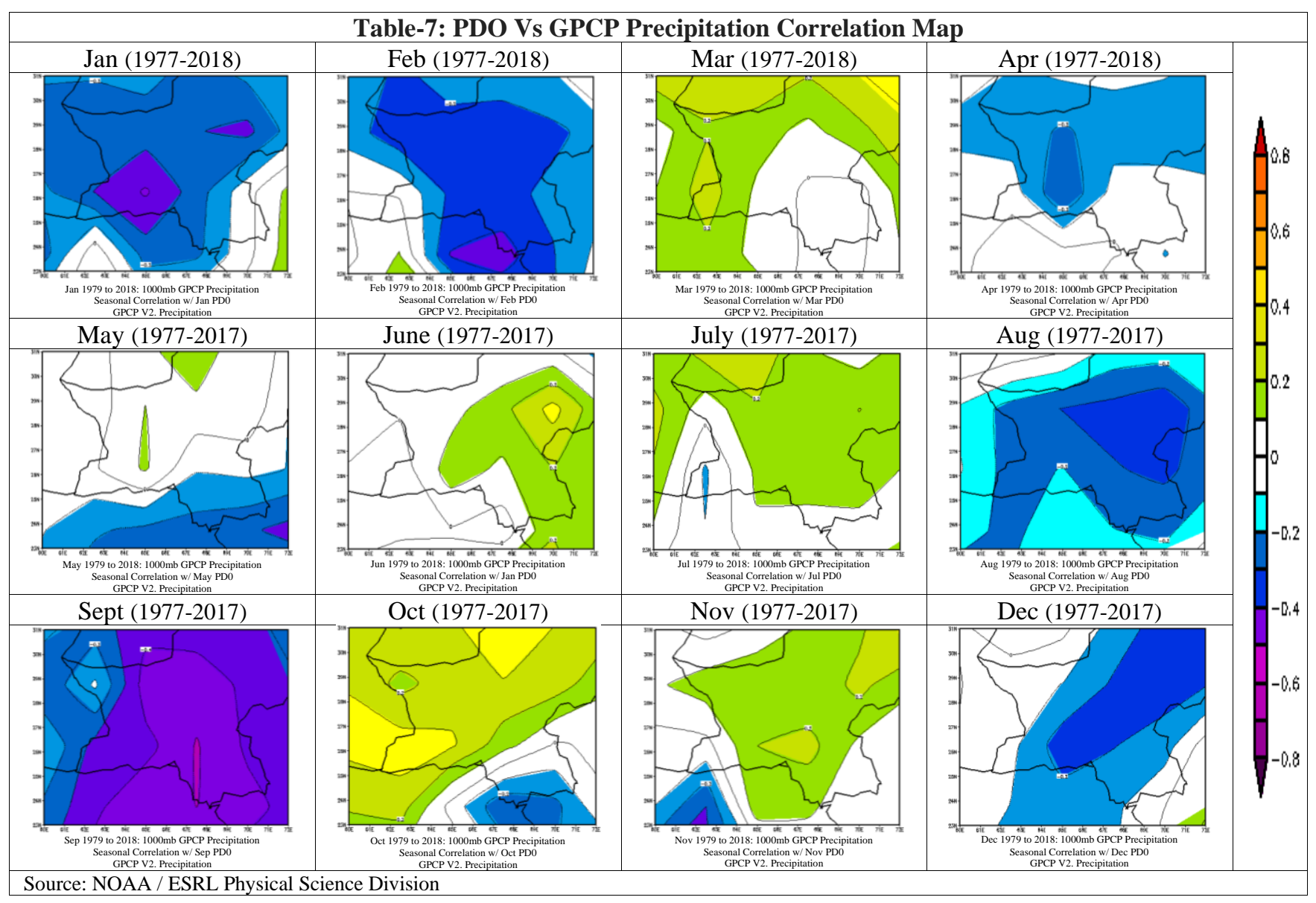

\subsubsection{Association of $\mathrm{QBO}$ with Precipitation}

The correlation contour map of Baluchistan (period 1977 to 2017 and months January to December) between QBO and GPCP precipitation is attached below. The correlation coefficient ranges from - 0.5 to 0.5 . The correlation map in Table- 8 shows that QBO has a negative significant correlation in May and September GPCP precipitation and positive significant correlation with October, November, and December GPCP precipitation

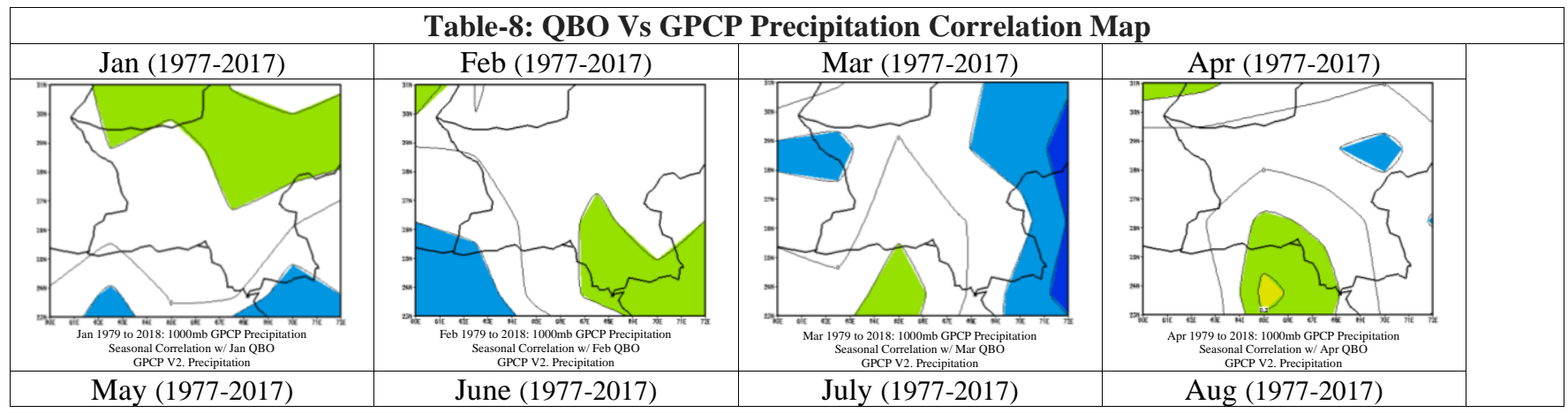




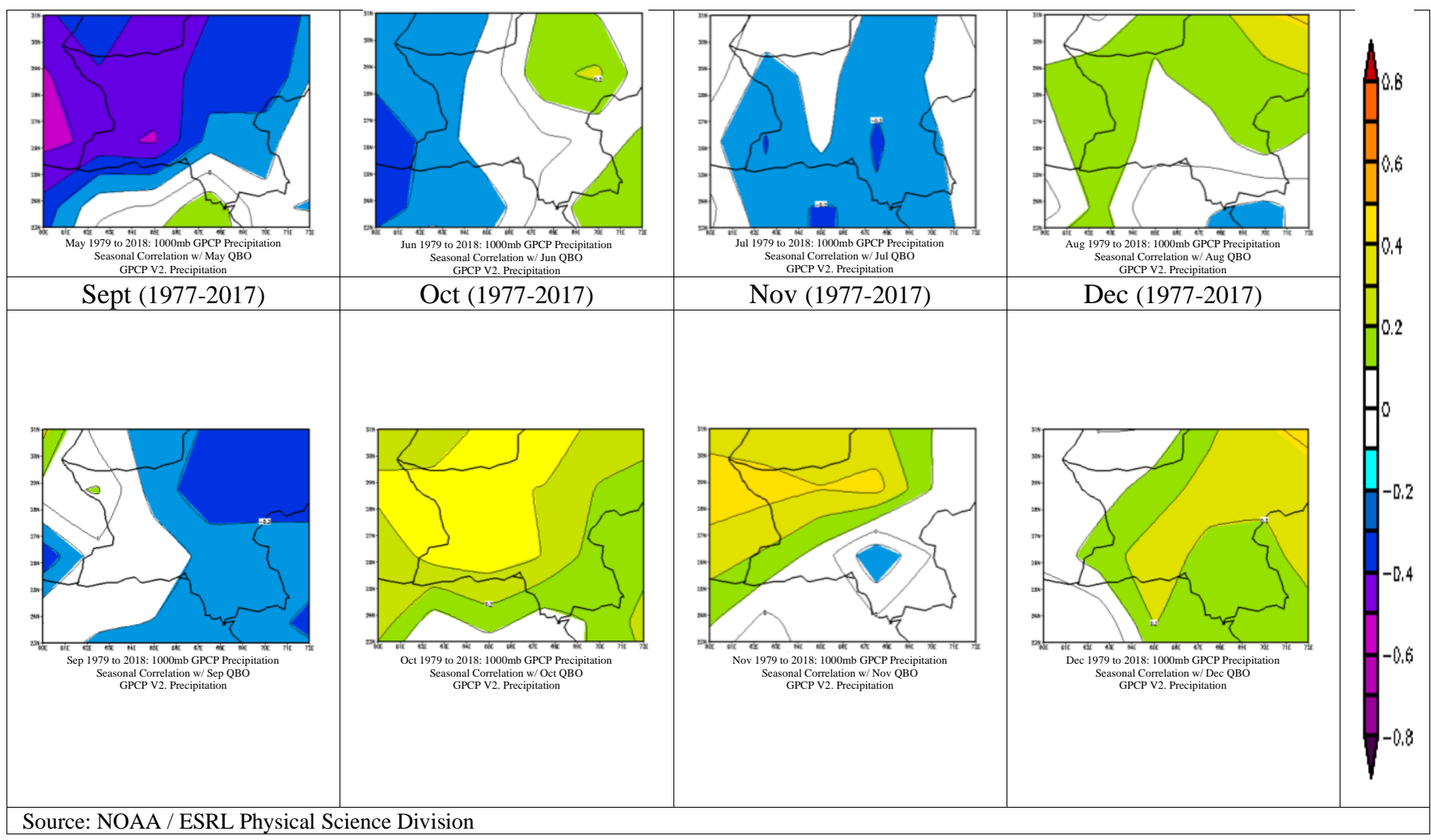

\subsubsection{Association of ENSO-MEI with Precipitation}

The correlation contour map of Baluchistan (period 1977 to 2017 and months January to December) between ENSO-MEI and GPCP precipitation is attached below. The correlation coefficient ranges from -0.5 to 0.5 . The correlation map in Table-9 shows that ENSO-MEI has a negative significant correlation with August GPCP precipitation and the positive significant correlation in October and November GPCP precipitation.

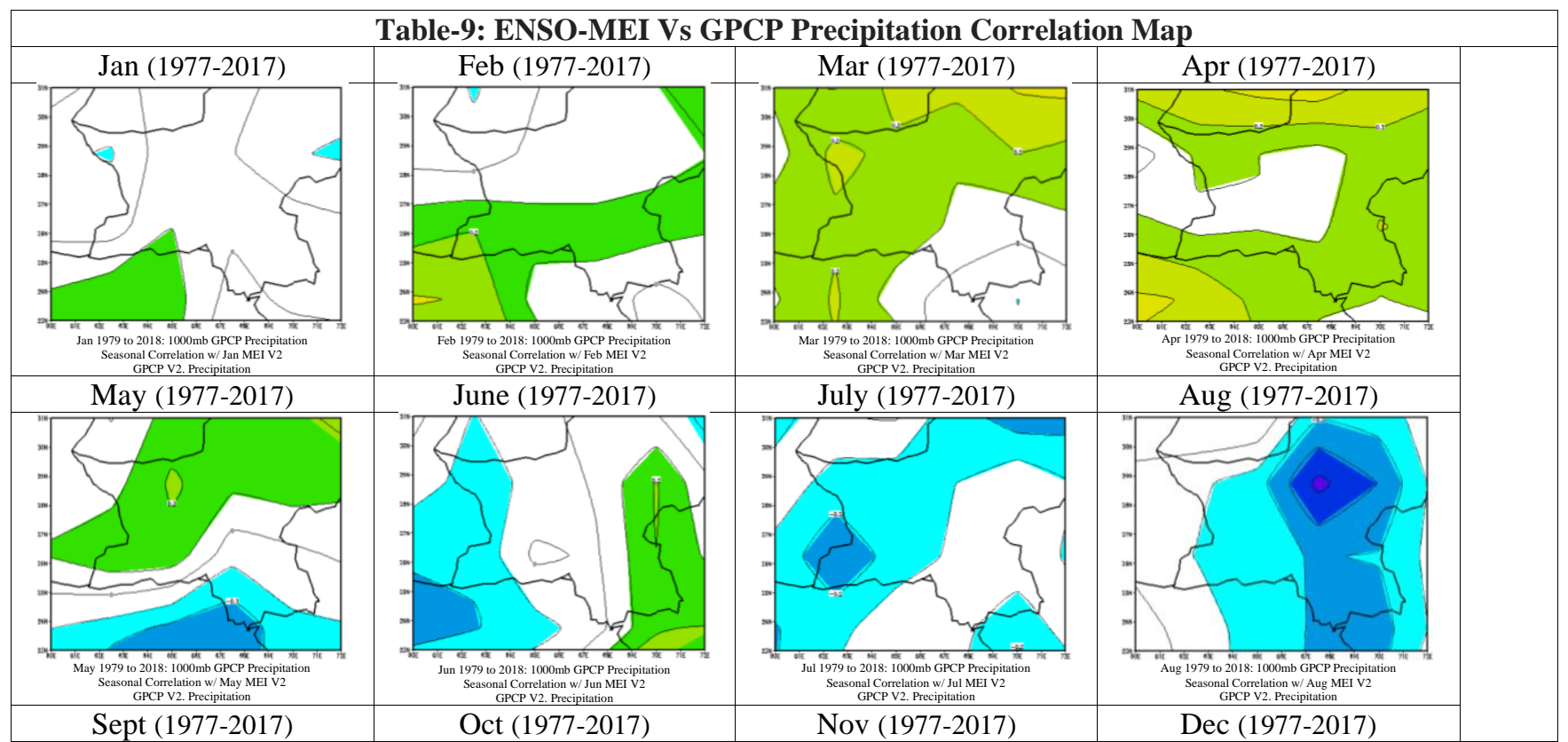




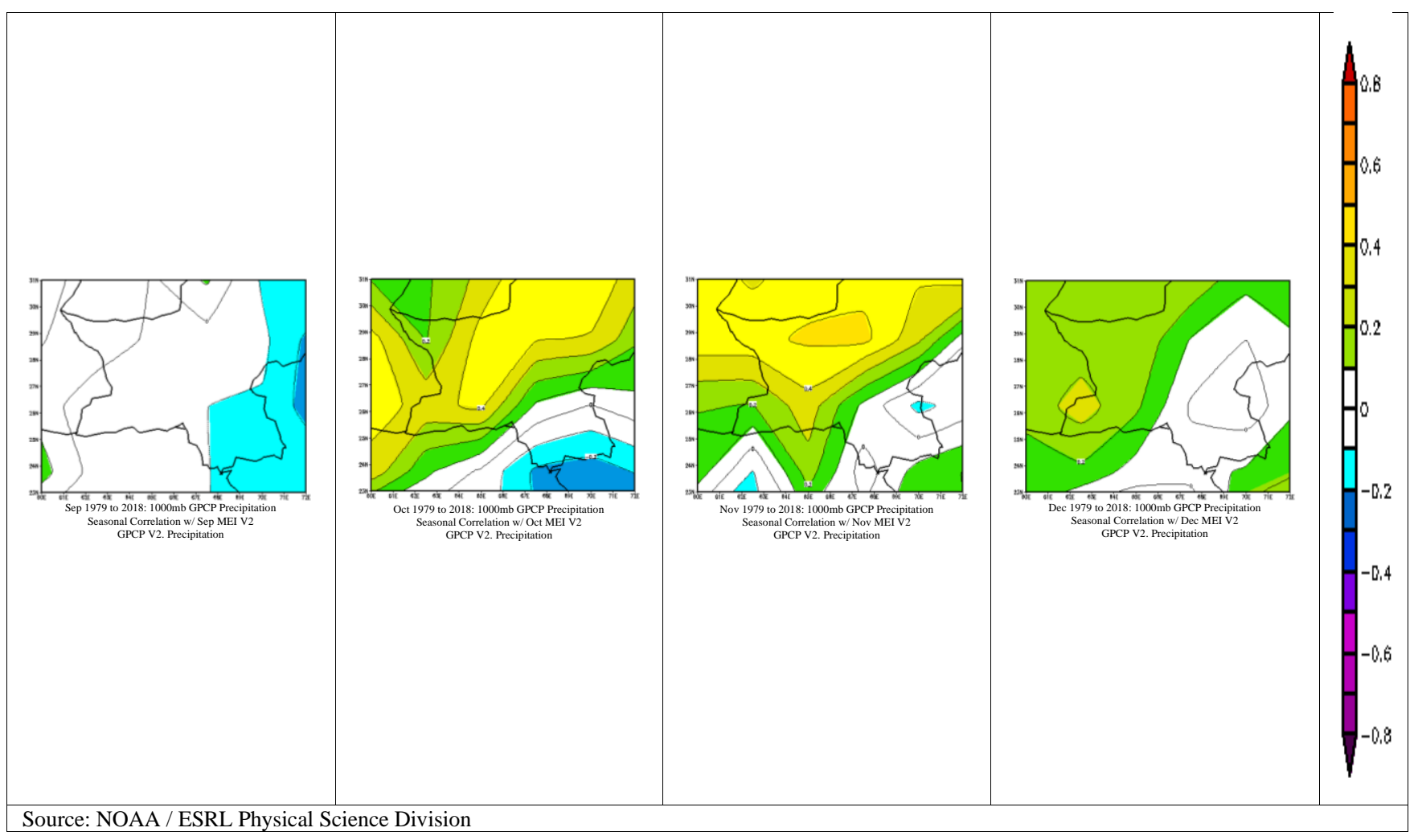

\subsubsection{Summarized Results of the Association of Climatic Indices with Monthly Precipitation}

Within Baluchistan, NAO shows a significant negative correlation in October, AO shows a significant positive correlation in January, November and a significant negative correlation in October, AMO shows a significant positive correlation in June, October, IOD shows a significant positive correlation in May, October, November and significant negative correlation in April, PDO shows significant positive correlation in October, and significant negative correlation in January, February, August, September, December, QBO shows significant positive correlation in October, November, December and significant negative correlation in May, September whereas ENSO-MEI shows significant positive correlation in October, November and significant negative correlation in August.

TABLE 10

SIGNIFICANT ASSOCIATION OF CLIMATIC INDICES WITH PRECIPITATION

\begin{tabular}{|c|c|c|c|c|c|c|c|}
\hline Months & NAO & $\mathrm{AO}$ & AMO & IOD & PDO & QBO & ENSO-MEI \\
\hline January & & $*$ & & & $(*)$ & & \\
\hline February & & & & & $(*)$ & & \\
\hline \multicolumn{8}{|l|}{ March } \\
\hline April & & & & $(*)$ & & & \\
\hline May & & & & $*$ & & $(*)$ & \\
\hline June & & & $*$ & & & & \\
\hline \multicolumn{8}{|l|}{ July } \\
\hline August & & & & & $(*)$ & & $(*)$ \\
\hline September & & & & & $(*)$ & $(*)$ & \\
\hline October & $(*)$ & $(*)$ & $*$ & $*$ & $*$ & $*$ & $*$ \\
\hline November & & $*$ & & $*$ & & $*$ & $*$ \\
\hline December & & & & & $(*)$ & $*$ & \\
\hline
\end{tabular}

Where $*$ is the significant positive correlation and $(*)$ is the significant negative correlation at $5 \%$ significance.

\subsection{Influence of Climatic and Atmospheric Indices on Precipitation Trends}

Several studies emphasize ENSO and NAO has affected the weather of Pakistan regionally and locally. Yadav. et al. (2009) suggests that the effect of ENSO has increased as compared to NAO. Afzal. M. et al. (2013) emphasizes that fresh studies needs to be carried out to study the recent influence of NAO on different regions of the globe. Rashid (2004) studied the impact 
of ENSO and state that ENSO has the negative effect on winter rainfall of Pakistan. Discussed that the rainfall in winter over Pakistan shows below normal behavior under the influence of ENSO (-ve) phase (i-e La Nina Condition). Arif, Tariq and Nadeem (2004) found out that ENSO does not have any significant adverse impact on August rainfall over Pakistan.

Iqbal and Athar (2017) investigated the correlation between precipitation and climatic indices through Pearson's correlation at $5 \%, 10 \%$ and $15 \%$ significant level. They found out that NAO shows a correlation with Baluchistan, positive phase of IOD have positive correlation, positive (negative) phase of AO shows correlation, PDO shows positive correlation and ENSO exhibits correlation in Baluchistan on monthly basis.

Pearson correlation only measures the strength of linear association between two variables. For a non-linear series, if correlation reports series, are insignificantly correlated, that simply means that there is no linear correlation between the two variables and there may be non-linear relationship. Precipitation and climate are greatly non-linear in nature and can upswing to butterfly effect (Abraham et al. 2001). Hence, the use of linear correlation to study the effect of climatic indices on precipitation may not yield reasonable results. Another approach to study the influence of climatic indices on precipitation is to study the variation in Trends in precipitation in the presence of climatic indices which are the covariates. Libisellar and Grimmvall, 2002 established that the correct Trends in precipitation can be assessed in the presence of the relevant covariates.

In this study the correct assessment of Trends in precipitation in the presence of influencing variables such as NAO, AO, AMO, IOD, PDO, QBO and ENSO-MEI is determined through the PMK test on monthly precipitation at individual station level. The Influence of response variables for the purpose of this study through the PMK test is classified in to insignificant, weak, moderate, and strong influence as described in the Table-11 below.

TABLE 11

CLASSIFICATION OF INFLUENCE TYPE

\begin{tabular}{clc}
\hline \hline S. No & \multicolumn{1}{c}{ Condition } & Influence Type \\
\hline \hline 1 & MK and PMK shows no significant trend & Insignificant \\
Weak & MK shows no significant trend, PMK shows \\
& significant trend or vice versa; OR both MK and & \\
& PMK shows significant trend; the addition of \\
& influencing variable changes the MK-Statistics by \\
& up to 10\%. & \\
& MK shows no significant trend, PMK shows \\
& significant trend or vice versa; OR both MK and \\
& $\begin{array}{l}\text { PMK shows significant trend; the addition of } \\
\text { influencing variable changes the MK-Statistics } \\
\text { from 10\% to 20\%. }\end{array}$ & Moderate \\
& $\begin{array}{l}\text { MK shows no significant trend, PMK shows } \\
\text { significant trend or vice versa; OR both MK and }\end{array}$ & Strong \\
& $\begin{array}{l}\text { PMK shows significant trend; the addition of } \\
\text { influencing variable changes the MK-Statistics } \\
\text { greater than 20\%. }\end{array}$ & \\
\hline \hline
\end{tabular}

\subsubsection{Climatic Indices on Monthly Precipitation at Individual Stations}

PMK test was run on the monthly precipitation time series being the response variable and the climatic indices being explanatory variables including NAO, AO, AMO, IOD, PDO, QBO and ENSO-MEI. The statistically significant trend in the presence of the relevant influencing variables is tabulated in the Table-11 to Table- 16.

a)

Influence of NAO on Precipitation

The PMK test shows that NAO has insignificant influence on precipitation of February, March, April, and August in Baluchistan. It shows that NAO has weak influence on precipitation of January, May, September, November, and December over some stations in Baluchistan. It also shows that NAO has weak to moderate (+ve) influence on June and moderate (-ve) influence on precipitation of July whereas NAO has strong (-ve) influence on October precipitation over Panjgur station in Baluchistan. The p-values of PMK at 5\% significance level along with Statistics and the influence of NAO are shown in the Table-11 below.

TABLE 11

INFLUENCE OF NAO ON PRECIPITATION TRENDS

\begin{tabular}{|c|c|c|c|c|c|c|c|c|c|}
\hline \multirow{2}{*}{ Months } & \multirow{2}{*}{ Stations } & \multicolumn{3}{|c|}{ Mann Kendall } & \multicolumn{3}{|c|}{$\begin{array}{c}\text { Partial Mann Kendall with NAO as } \\
\text { Covariate }\end{array}$} & \multirow{2}{*}{$\begin{array}{l}\text { \% Change in MK- } \\
\text { Statistics due to NAO } \\
\text { as Covariate }\end{array}$} & \multirow{2}{*}{$\begin{array}{l}\text { Influence } \\
\text { Type }\end{array}$} \\
\hline & & P-value & MK-Statistic & Trend Type & P-value & PMK-Statistic & Trend Type & & \\
\hline \multirow{2}{*}{ January } & Barakhan & 0.0462 & -177 & Decreasing & 0.048 & $\begin{array}{l}-174.1 \\
\end{array}$ & Decreasing & $1.64 \%$ & Weak \\
\hline & Quetta & 0.0119 & -224 & Decreasing & 0.0121 & -223.4 & Decreasing & $0.27 \%$ & Weak \\
\hline
\end{tabular}




\begin{tabular}{ccccccccccc} 
& Zhob & 0.0239 & -201 & Decreasing & 0.0245 & -196.8 & Decreasing & $2.09 \%$ & Weak \\
May & Ormara & 0.0063 & -205 & Decreasing & 0.0084 & -195.9 & Decreasing & $4.44 \%$ & Weak \\
& Barakhan & 0.0493 & 175 & Increasing & 0.0576 & 168.8 & Increasing & $3.54 \%$ & Weak \\
June & Quetta & 0.0126 & 206 & Increasing & 0.0338 & 165.5 & Increasing & $19.66 \%$ & Moderate \\
July & Panjgur & 0.0228 & -195 & Decreasing & 0.0427 & -171.7 & Decreasing & $11.95 \%$ & Moderate \\
September & Quetta & 0.0314 & 153 & Increasing & 0.0258 & 156.8 & Increasing & $2.48 \%$ & Weak \\
October & Panjgur & 0.1313 & -76 & Decreasing & 0.0491 & -92 & Decreasing & $21.05 \%$ & Strong \\
November & Barakhan & 0.0107 & -211 & Decreasing & 0.0063 & -222.1 & Decreasing & $5.26 \%$ & Weak \\
& Dalbandin & 0.01648 & -208 & Decreasing & 0.0215 & -197.8 & Decreasing & $4.90 \%$ & Weak \\
December & Jiwani & 0.0037 & -245 & Decreasing & 0.0063 & -221.6 & Decreasing & $9.55 \%$ & Weak \\
& Khuzdar & 0.0401 & -178 & Decreasing & 0.0574 & -162 & Decreasing & $8.99 \%$ & Weak \\
& Panjgur & 0.0351 & -176 & Decreasing & 0.0349 & -176.2 & Decreasing & $0.11 \%$ & Weak \\
\hline \hline
\end{tabular}

\section{b) Influence of AO on Precipitation}

The PMK test shows that AO has insignificant influence on precipitation of February, March, April, August, and October in Baluchistan. It shows that AO has weak influence on precipitation of January, May, June, November, and December over some stations in Baluchistan. It also shows that AO has moderate (-ve) influence on precipitation of July but moderate (+ve) influence on precipitation of September over some stations in Baluchistan. The p-values of PMK at 5\% significance level along with Statistics and the influence of AO are shown in the Table-12 below.

TABLE-12

INFLUENCE OF AO ON PRECIPITATION TRENDS

\begin{tabular}{|c|c|c|c|c|c|c|c|c|c|}
\hline \multirow[t]{2}{*}{ Months } & \multirow[t]{2}{*}{ Stations } & \multicolumn{3}{|c|}{ Mann Kendall } & \multicolumn{3}{|c|}{$\begin{array}{l}\text { Partial Mann Kendall with } \mathrm{AO} \text { as } \\
\text { Covariate }\end{array}$} & \multirow{2}{*}{$\begin{array}{c}\% \text { Change in } \mathrm{MK}- \\
\text { Statistics due to } \mathrm{AO} \text { as } \\
\text { Covariate }\end{array}$} & \multirow{2}{*}{$\begin{array}{l}\text { Influence } \\
\text { Type }\end{array}$} \\
\hline & & P-value & MK-Statistic & Trend Type & P-value & PMK-Statistic & Trend Type & & \\
\hline \multirow{3}{*}{ January } & Barakhan & 0.0462 & -177 & Decreasing & 0.0397 & -179 & Decreasing & $1.13 \%$ & Weak \\
\hline & Quetta & 0.0119 & -224 & Decreasing & 0.0113 & -225.4 & Decreasing & $0.63 \%$ & Weak \\
\hline & Zhob & 0.0239 & -201 & Decreasing & 0.0268 & -196.1 & Decreasing & $2.44 \%$ & Weak \\
\hline May & Ormara & 0.0063 & -205 & Decreasing & 0.0069 & -202.5 & Decreasing & $1.22 \%$ & Weak \\
\hline \multirow[t]{2}{*}{ June } & Quetta & 0.0126 & 206 & Increasing & 0.0112 & 207.5 & Increasing & $0.73 \%$ & Weak \\
\hline & Sibbi & 0.0259 & 186 & Increasing & 0.0259 & 186 & Increasing & $0.00 \%$ & ---- \\
\hline July & Panjgur & 0.0228 & -195 & Decreasing & 0.0351 & -174.7 & Decreasing & $10.41 \%$ & Moderate \\
\hline September & Quetta & 0.0314 & 153 & Increasing & 0.0489 & 137.7 & Increasing & $10.00 \%$ & Moderate \\
\hline November & Barakhan & 0.0107 & -211 & Decreasing & -0.0046 & -225.3 & Decreasing & $6.78 \%$ & Weak \\
\hline \multirow{3}{*}{ December } & Dalbandin & 0.01648 & -208 & Decreasing & 0.0132 & -213 & Decreasing & $2.40 \%$ & Weak \\
\hline & Jiwani & 0.0037 & -245 & Decreasing & 0.0041 & -240.3 & Decreasing & $1.92 \%$ & Weak \\
\hline & Panjgur & 0.0351 & -176 & Decreasing & 0.0317 & -178.9 & Decreasing & $1.65 \%$ & Weak \\
\hline
\end{tabular}

c) Influence of AMO on Precipitation

Both Mann Kendall and Partial Mann Kendall tests shows no significant increasing or decreasing Trends in any of the 13 stations of Baluchistan as such AMO does not have any significant influence on precipitation in Baluchistan.5.2.1.2 Influence of $\mathrm{AO}$ on Precipitation

\section{d) Influence of IOD on Precipitation}

The PMK test shows that IOD has insignificant influence on precipitation of February, March, April, August and October in Baluchistan. It shows that IOD has weak influence on precipitation of January, June, July and December over some stations in Baluchistan. It also shows that IOD has moderate (-ve) influence on precipitation of May, moderate to strong (-ve) influence on precipitation of November and weak to moderate (-ve) influence on precipitation over some stations in Baluchistan whereas NAO has strong (+ve) influence on September precipitation over the Quetta station in Baluchistan. The p-values of PMK at $5 \%$ significance level along with Statistics and the influence of IOD is shown in the Table-13 below.

TABLE 13

INFLUENCE OF IOD ON PRECIPITATION TRENDS

\begin{tabular}{|c|c|c|c|c|c|c|c|c|c|}
\hline \multirow[t]{2}{*}{ Months } & \multirow[t]{2}{*}{ Stations } & \multicolumn{3}{|c|}{ Mann Kendall } & \multicolumn{3}{|c|}{$\begin{array}{l}\text { Partial Mann Kendall with IOD as } \\
\text { Covariate }\end{array}$} & \multirow{2}{*}{$\begin{array}{c}\% \text { Change in MK- } \\
\text { Statistics due to IOD as } \\
\text { Covariate }\end{array}$} & \multirow{2}{*}{$\begin{array}{l}\text { Influence } \\
\text { Type }\end{array}$} \\
\hline & & P-value & MK-Statistic & Trend Type & P-value & PMK-Statistic & Trend Type & & \\
\hline \multirow{2}{*}{ January } & Barakhan & 0.0462 & -177 & Decreasing & 0.0338 & -188 & Decreasing & $6.21 \%$ & Weak \\
\hline & Quetta & 0.0119 & -224 & Decreasing & 0.0086 & -233.4 & Decreasing & $4.20 \%$ & Weak \\
\hline
\end{tabular}




\begin{tabular}{cccccccccc|c}
\multirow{5}{*}{ May } & Zhob & 0.0239 & -201 & Decreasing & 0.0124 & -221 & Decreasing & $9.95 \%$ & Weak \\
& Ormara & 0.0063 & -205 & Decreasing & 0.0132 & -182.6 & Decreasing & $10.93 \%$ & Moderate \\
& Barakhan & 0.0493 & 175 & Increasing & 0.0485 & 175.6 & Increasing & $0.34 \%$ & Weak \\
June & Quetta & 0.0126 & 206 & Increasing & 0.0151 & 200.3 & Increasing & $2.77 \%$ & Weak \\
& Sibbi & 0.0259 & 186 & Increasing & 0.0304 & 180.5 & Increasing & $2.96 \%$ & Weak \\
& Kalat & 0.0541 & -167 & Decreasing & 0.0424 & -175.5 & Decreasing & $5.09 \%$ & Weak \\
July & Panjgur & 0.0228 & -195 & Decreasing & 0.0198 & -199.4 & Decreasing & $2.26 \%$ & Weak \\
September & Quetta & 0.0314 & 153 & Increasing & 0.1222 & 102.1 & Increasing & $33.27 \%$ & Strong \\
& Barakhan & 0.0107 & -211 & Decreasing & 0.0018 & -251.3 & Decreasing & $19.10 \%$ & Moderate \\
November & Jiwani & 0.24 & -72 & Decreasing & 0.035 & -121.1 & Decreasing & $68.19 \%$ & Strong \\
& Khuzdar & 0.0645 & -151 & Decreasing & 0.0362 & -170.2 & Decreasing & $12.72 \%$ & Moderate \\
& Dalbandin & 0.01648 & -208 & Decreasing & 0.0116 & -217.6 & Decreasing & $4.62 \%$ & Weak \\
& Jiwani & 0.0037 & -245 & Decreasing & 0.0027 & -252.2 & Decreasing & $2.94 \%$ & Weak \\
& Khuzdar & 0.0401 & -178 & Decreasing & 0.0205 & -197.5 & Decreasing & $10.96 \%$ & Moderate \\
\hline \multirow{5}{*}{ December } & Panjgur & 0.0351 & -176 & Decreasing & 0.0202 & -191.4 & Decreasing & $8.75 \%$ & Weak \\
& Quetta & 0.0574 & -169 & Decreasing & 0.0369 & -183.6 & Decreasing & $8.64 \%$ & Weak & Weak \\
\hline \hline
\end{tabular}

\section{e) Influence of PDO on Precipitation}

The PMK test shows that PDO has insignificant influence on precipitation of February, March, April, August and October in Baluchistan. It shows that PDO has weak influence on precipitation of January, June, November and December over some stations in Baluchistan. It also shows that PDO has moderate influence on precipitation of May, moderate (-ve) influence on precipitation of July but moderate (+ve) influence on precipitation of September over some stations in Baluchistan. The $\mathrm{p}$ values of PMK at 5\% significance level along with Statistics and the influence of PDO is shown in the Table-14.

TABLE 14

INFLUENCE OF PDO ON PRECIPITATION TRENDS

\begin{tabular}{|c|c|c|c|c|c|c|c|c|c|}
\hline \multirow[t]{2}{*}{ Months } & \multirow[t]{2}{*}{ Stations } & \multicolumn{3}{|c|}{ Mann Kendall } & \multicolumn{3}{|c|}{$\begin{array}{l}\text { Partial Mann Kendall with PDO as } \\
\text { Covariate }\end{array}$} & \multirow{2}{*}{$\begin{array}{c}\% \text { Change in MK- } \\
\text { Statistics due to PDO } \\
\text { as Covariate }\end{array}$} & \multirow{2}{*}{$\begin{array}{c}\text { Influence } \\
\text { Type }\end{array}$} \\
\hline & & P-value & MK-Statistic & Trend Type & P-value & PMK-Statistic & Trend Type & & \\
\hline \multirow{3}{*}{ January } & Barakhan & 0.0462 & -177 & Decreasing & 0.0325 & -185.9 & Decreasing & $5.03 \%$ & Weak \\
\hline & Quetta & 0.0119 & -224 & Decreasing & 0.0097 & -228.8 & Decreasing & $2.14 \%$ & Weak \\
\hline & Zhob & 0.0239 & -201 & Decreasing & 0.0219 & -203.5 & Decreasing & $1.24 \%$ & Weak \\
\hline \multirow{3}{*}{ May } & Ormara & 0.0063 & -205 & Decreasing & 0.0116 & -174.6 & Decreasing & $14.83 \%$ & Moderate \\
\hline & Quetta & 0.0607 & 165 & Increasing & 0.0246 & 190.1 & Increasing & $15.21 \%$ & Moderate \\
\hline & Sibbi & 0.0678 & 154 & Increasing & 0.0254 & 180 & Increasing & $16.88 \%$ & Moderate \\
\hline \multirow{3}{*}{ June } & Barakhan & 0.0493 & 175 & Increasing & 0.0357 & 183.4 & Increasing & $4.80 \%$ & Weak \\
\hline & Quetta & 0.0126 & 206 & Increasing & 0.0103 & 210.5 & Increasing & $2.18 \%$ & Weak \\
\hline & Sibbi & 0.0259 & 186 & Increasing & 0.0258 & 186.2 & Increasing & $0.11 \%$ & Weak \\
\hline July & Panjgur & 0.0228 & -195 & Decreasing & 0.0408 & -173.4 & Decreasing & $11.08 \%$ & Moderate \\
\hline September & Quetta & 0.0314 & 153 & Increasing & 0.0536 & 135.6 & Increasing & $11.37 \%$ & Moderate \\
\hline November & Barakhan & 0.0107 & -211 & Decreasing & 0.0124 & -205.9 & Decreasing & $2.42 \%$ & Weak \\
\hline \multirow{4}{*}{ December } & Jiwani & 0.0037 & -245 & Decreasing & 0.0038 & -242.7 & Decreasing & $0.94 \%$ & Weak \\
\hline & Khuzdar & 0.0401 & -178 & Decreasing & 0.0304 & -182.7 & Decreasing & $2.64 \%$ & Weak \\
\hline & Panjgur & 0.0351 & -176 & Decreasing & 0.0294 & -179.3 & Decreasing & $1.88 \%$ & Weak \\
\hline & Zhob & 0.0663 & -160 & Decreasing & 0.0469 & -165.9 & Decreasing & $3.69 \%$ & Weak \\
\hline
\end{tabular}

The PMK test shows that QBO has insignificant influence on precipitation of February, March, April, August and October in Baluchistan, whereas it shows that NAO has weak influence on precipitation of January, May, June, July, September, November and December over some stations in Baluchistan. The p-values of PMK at 5\% significance level along with Statistics and the influence of QBO is shown in the Table-15 below.

TABLE 15

INFLUENCE OF QBO ON PRECIPITATION TRENDS

\begin{tabular}{|c|c|c|c|c|c|c|c|c|c|}
\hline \multirow{2}{*}{ Months } & \multirow{2}{*}{ Stations } & \multicolumn{3}{|c|}{ Mann Kendall } & \multicolumn{3}{|c|}{$\begin{array}{l}\text { Partial Mann Kendall with QBO as } \\
\text { Covariate }\end{array}$} & \multirow{2}{*}{$\begin{array}{c}\% \text { Change in } \mathrm{MK}- \\
\text { Statistics due to QBO } \\
\text { as Covariate } \\
\end{array}$} & \multirow{2}{*}{$\begin{array}{l}\text { Influence } \\
\text { Type }\end{array}$} \\
\hline & & P-value & MK-Statistic & Trend Type & P-value & PMK-Statistic & Trend Type & & \\
\hline \multirow[t]{3}{*}{ January } & Barakhan & 0.0462 & -177 & Decreasing & 0.047 & -176.2 & Decreasing & $0.45 \%$ & Weak \\
\hline & Quetta & 0.0119 & -224 & Decreasing & 0.0108 & -226.2 & Decreasing & $0.98 \%$ & Weak \\
\hline & Zhob & 0.0239 & -201 & Decreasing & -0.0251 & -197.6 & Decreasing & $1.69 \%$ & Weak \\
\hline
\end{tabular}




\begin{tabular}{|c|c|c|c|c|c|c|c|c|c|}
\hline \multirow[t]{2}{*}{ May } & Ormara & 0.0063 & -205 & Decreasing & 0.0062 & -205.1 & Decreasing & $0.05 \%$ & Weak \\
\hline & Quetta & 0.0607 & 165 & Increasing & 0.0394 & 165.8 & Increasing & $0.48 \%$ & Weak \\
\hline \multirow[t]{3}{*}{ June } & Barakhan & 0.0493 & 175 & Increasing & 0.0419 & 175.3 & Increasing & $0.17 \%$ & Weak \\
\hline & Quetta & 0.0126 & 206 & Increasing & 0.0123 & 205.9 & Increasing & $0.05 \%$ & Weak \\
\hline & Sibbi & 0.0259 & 186 & Increasing & 0.0251 & 185.9 & Increasing & $0.05 \%$ & Weak \\
\hline July & Panjgur & 0.0228 & -195 & Decreasing & 0.0232 & -193.3 & Decreasing & $0.87 \%$ & Weak \\
\hline September & Quetta & 0.0314 & 153 & Increasing & 0.0303 & 150.7 & Increasing & $1.50 \%$ & Weak \\
\hline November & Barakhan & 0.0107 & -211 & Decreasing & 0.0074 & -208.5 & Decreasing & $1.18 \%$ & Weak \\
\hline \multirow[t]{4}{*}{ December } & Dalbandin & 0.01648 & -208 & Decreasing & 0.0166 & -207.1 & Decreasing & $0.43 \%$ & Weak \\
\hline & Jiwani & 0.0037 & -245 & Decreasing & 0.0036 & -245.1 & Decreasing & $0.04 \%$ & Weak \\
\hline & Khuzdar & 0.0401 & -178 & Decreasing & 0.0406 & -177.2 & Decreasing & $0.45 \%$ & Weak \\
\hline & Panjgur & 0.0351 & -176 & Decreasing & 0.0355 & -174.5 & Decreasing & $0.85 \%$ & Weak \\
\hline
\end{tabular}

The PMK test shows that ENSO-MEI has insignificant influence on precipitation of February, March, April, August and October in Baluchistan, whereas it shows that ENSO-MEI has weak influence on precipitation of January, May, June, July, and September over some stations in Baluchistan. It also shows that ENSO-MEI has strong to moderate negative influence on precipitation of November and December over some stations in Baluchistan. The p-values of PMK at 5\% significance level along with Statistics and influence of ENSO-MEI is shown in the Table-16 below.

TABLE 16

INFLUENCE OF ENSO-MEI ON PRECIPITATION TRENDS

\begin{tabular}{|c|c|c|c|c|c|c|c|c|c|}
\hline \multirow[t]{2}{*}{ Months } & \multirow[t]{2}{*}{ Stations } & \multicolumn{3}{|c|}{ Mann Kendall } & \multicolumn{3}{|c|}{$\begin{array}{l}\text { Partial Mann Kendall with ENSO-MEI } \\
\text { as Covariate }\end{array}$} & \multirow{2}{*}{$\begin{array}{c}\text { \% Change in MK- } \\
\text { Statistics due to ENSO- } \\
\text { MEI as Covariate }\end{array}$} & \multirow{2}{*}{$\begin{array}{l}\text { Influence } \\
\text { Type }\end{array}$} \\
\hline & & P-value & MK-Statistic & Trend Type & P-value & PMK-Statistic & Trend Type & & \\
\hline \multirow{3}{*}{ January } & Barakhan & 0.0462 & -177 & Decreasing & 0.0437 & -182.5 & Decreasing & $3.11 \%$ & Weak \\
\hline & Quetta & 0.0119 & -224 & Decreasing & 0.0161 & -213 & Decreasing & $4.91 \%$ & Weak \\
\hline & Zhob & 0.0239 & -201 & Decreasing & 0.0362 & -183.7 & Decreasing & $8.61 \%$ & Weak \\
\hline May & Ormara & 0.0063 & -205 & Decreasing & 0.0046 & -211.4 & Decreasing & $3.12 \%$ & Weak \\
\hline \multirow[t]{2}{*}{ June } & Quetta & 0.0126 & 206 & Increasing & 0.0416 & 200.8 & Increasing & $2.52 \%$ & Weak \\
\hline & Sibbi & 0.0259 & 186 & Increasing & 0.0298 & 180.5 & Increasing & $2.96 \%$ & Weak \\
\hline \multirow[t]{2}{*}{ July } & Kalat & 0.0541 & -167 & Decreasing & 0.0472 & -169.1 & Decreasing & $1.26 \%$ & Weak \\
\hline & Panjgur & 0.0228 & -195 & Decreasing & 0.0207 & -196.5 & Decreasing & $0.77 \%$ & Weak \\
\hline \multirow{3}{*}{$\begin{array}{l}\text { September } \\
\text { November }\end{array}$} & Quetta & 0.0314 & 153 & Increasing & 0.0241 & 159.8 & Increasing & $4.44 \%$ & Weak \\
\hline & Barakhan & 0.0107 & -211 & Decreasing & 0.0239 & -165.3 & Decreasing & $21.66 \%$ & Strong \\
\hline & Dalbandin & 0.0165 & -208 & Decreasing & 0.0384 & -171.7 & Decreasing & $17.45 \%$ & Moderate \\
\hline \multirow{2}{*}{ December } & Khuzdar & 0.0401 & -178 & Decreasing & 0.0751 & -150.5 & Decreasing & $15.45 \%$ & Moderate \\
\hline & Panjgur & 0.0351 & -176 & Decreasing & 0.0724 & -144.9 & Decreasing & $17.67 \%$ & Moderate \\
\hline
\end{tabular}

\subsubsection{Summarized Results of Climatic Indices on Monthly Precipitation at Individual Stations}

The Table-17 shows that NAO, AO, IOD, PDO, and ENSO-MEI mostly has weak influence on precipitation in Baluchistan except they have moderate to strong effect in some months. NAO has moderate influence in June and July but strong influence in October, AO has moderate influence in July and September, IOD has a moderate effect in May, November and December, but has a strong effect in September and November, PDO has a moderate effect in May, July and September, QBO has weak influence all year whereas ENSO has a moderate effect in December but has a strong effect in November.

TABLE 17

SUMMARIZED RESUlTS OF INFLUENCE OF CLIMATIC INDICES ON MONTHLY PRECIPITATION AT INDIVIDUAL STATIONS

\begin{tabular}{|c|c|c|c|c|c|c|c|}
\hline \multirow{2}{*}{ Months } & \multirow{2}{*}{ Stations } & \multicolumn{6}{|c|}{ Covariates-Atmospheric and Climatic Indices } \\
\hline & & NAO & $\mathrm{AO}$ & IOD & PDO & QBO & ENSO-MEI \\
\hline \multirow{3}{*}{ January } & Barakhan & Weak & Weak & Weak & Weak & Weak & Weak \\
\hline & Quetta & Weak & Weak & Weak & Weak & Weak & Weak \\
\hline & Zhob & Weak & Weak & Weak & Weak & Weak & Weak \\
\hline \multirow[b]{2}{*}{ May } & Ormara & Weak & Weak & Moderate & Moderate & Weak & Weak \\
\hline & Quetta & ----- & ----- & ----- & Moderate & ----- & ----- \\
\hline \multirow{3}{*}{ June } & Barakhan & Weak & Weak & Weak & Weak & Weak & Weak \\
\hline & Quetta & Moderate & Weak & Weak & Weak & Weak & Weak \\
\hline & Sibbi & ----- & ----- & Weak & Weak & Weak & Weak \\
\hline July & Kalat & ----- & ----- & Weak & ----- & ----- & Weak \\
\hline
\end{tabular}




\begin{tabular}{|c|c|c|c|c|c|c|c|}
\hline \multirow{4}{*}{$\begin{array}{c}\text { September } \\
\text { October }\end{array}$} & Panjgur & Moderate & Moderate & Weak & Moderate & Weak & Weak \\
\hline & Quetta & Weak & Moderate & Strong & Moderate & Weak & Weak \\
\hline & Panjgur & Strong & ----- & ----- & ----- & ----- & ----- \\
\hline & Barakhan & Weak & Weak & Moderate & Weak & Weak & Strong \\
\hline \multirow[t]{2}{*}{ November } & Jiwani & ----- & ----- & Strong & ----- & ----- & ----- \\
\hline & Khuzdar & ----- & ----- & Moderate & ----- & ----- & ----- \\
\hline \multirow{6}{*}{ December } & Dalbandin & Weak & Weak & Weak & Weak & Weak & Moderate \\
\hline & Jiwani & Weak & Weak & Weak & Weak & Weak & Moderate \\
\hline & Khuzdar & Weak & Weak & Moderate & Weak & Weak & Moderate \\
\hline & Panjgur & Weak & Weak & Weak & Weak & Weak & Moderate \\
\hline & Quetta & ----- & ----- & Weak & ----- & ----- & ----- \\
\hline & Zhob & ----- & ----- & Weak & Weak & ----- & ----- \\
\hline
\end{tabular}

\section{Conclusions}

The results of linear correlation are in line with the partial Mann Kendall in some instances and different in others because of the nonlinear nature of the precipitation which is indicative of that the Partial Mann Kendall is most suitable method to determine the influence in precipitation rather than the linear correlation. Alternatively, the correlation shall be performed on the positive (negative) phases of the explanatory variable (climate indices) separately with the corresponding year precipitation time series.

Baluchistan receives its greater portion of the Precipitation in winter and spring months. Decreasing Trends in precipitation are observed in the winter and Spring Months of November, December January and May, when the time series data is analyzed from 1977 to 2017 through Mann Kendall Test, which confirms that the Baluchistan is receiving lesser precipitation since the past few decades. It is also observed ENSO-MEI and IOD has strong to moderate influence on the precipitation Trends in these months while NAO, AO, PDO and QBO has weak influence on precipitation when tested with Partial Mann Kendall test using precipitation as the response variable and climatic indices as explanatory variables. This confirms the findings in the previous study with respect to ENSO and NAO that in recent years ENSO is affecting the climate more than AO/NAO and the latter is losing control in determining the variability in climate in the winter months on North Western Indian precipitation which is adjacent to Pakistan. Decreasing trends are observed in the months of October when continental air prevails, and NAO has a strong influence on precipitation in this month. Increasing Trends are observed in the months of June and September whereas decreasing trends are observed in the month of July in the areas close to Punjab and Sindh, but in these Monsoon months the amount of rainfall is lesser which would affect the overall rainfall in Baluchistan to a lesser extent. It is observed that NAO, $\mathrm{AO}$ and PDO have strong to a moderate influence on precipitation in these months whereas ENSO-MEI, IOD and QBO has a weak influence on precipitation.

The study also shows that QBO and AMO do not directly influenced precipitation in the Baluchistan, but the linear combination of AMO with NAO/AO, QBO with IOD (EQUINOO/DMI) and ENSO may have noticeable influence on the winter and Monsoon rainfalls. Similarly, the linear combination of PDO with IDO (EQUINOO/DMI) and ENSO may also be studied.

Conflicts of Interest: The authors declare no conflict of interest.

\section{References}

1. Aamir, E. and Hassan, I., 2018, September. Trend analysis in precipitation at individual and regional levels in Baluchistan, Pakistan. In IOP Conference Series: Materials Science and Engineering; IOP Publishing: Bristol, UK (p. 012042).

2. Abraham A., Sajith N., Joseph B. (2001). Will We Have a Wet Summer? Long-term Rain Forecasting Using Soft Computing Models: Modelling and Simulation, Publication of the Society for Computer Simulation International, Prague, Czech Republic, 1044-1048

3. Afzal, M., Haroon, M.A., Rana, A.S. and Imran, A., 2013. Influence of North Atlantic oscillations and Southern oscillations on winter precipitation of Northern Pakistan. Pakistan Journal of Meteorology, 9(18).

4. Ahmad I, Tang D, Wang TF, Wang M, Wagan B (2015) Precipitation trends over time using Mann-Kendall and Spearman's rho tests in Swat river basin, Pakistan. Adv Meteorol 2015: Article ID 431860

5. Ali, S., Khalid, B., Kiani, R.S., Babar, R., Nasir, S., Rehman, N., Adnan, M. and Goheer, M.A., 2020. Spatio-temporal variability of summer monsoon onset over Pakistan. Asia-Pacific Journal of Atmospheric Sciences, 56(1), pp.147-172 
6. Athar, H., 2015. Teleconnections and variability in observed rainfall over Saudi Arabia during 1978-2010. Atmospheric Science Letters, 16(3), pp.373-379.

7. Ashraf, M.; Routray, J.K. Spatio-temporal characteristics of precipitation and drought in Balochistan Province, Pakistan. Nat. Hazards 2015, 77, 229-254. [CrossRef].

8. Ashok, K., Behera, S.K., Rao, S.A., Weng, H. and Yamagata, T., 2007. El Niño Modoki and its possible teleconnection. Journal of Geophysical Research: Oceans, 112(C11).

9. Bastiaanssen W.G.M and Samia Ali, 2003. A new crop yield forecasting model based on satellite measurements applied across the Indus Basin, Pakistan, Agriculture Ecosystems \& Environment, 94(3), 321-340

10. Burn D. H. and Elnur M. A. H., "Detection of hydrologic trends and variability," Journal of Hydrology, vol. 255, no. 14, pp. 107-122, 2002

11. Chaouche K., Neppel L., Dieulin C. et al., "Analyses of precipitation, temperature and evapotranspiration in a French Mediterranean region in the context of climate change," Comptes Rendus: Geoscience, vol. 342, no. 3, pp. 234-243, 2010.

12. Gadiwala, M.S. and Burke, F., 2019. Climate change and precipitation in Pakistan-a meteorological prospect. International Journal of Economic and Environmental Geology, pp.10-15

13. Global climate $\quad$ risk $\quad$ index 2019 https://www.germanwatch.org/sites/germanwatch.org/files/Global\%20Climate\%20Risk\%20Index\%202019_2.pdf.

14. Hajani, E., Rahman, A. and Ishak, E., 2017. Trends in extreme rainfall in the state of New South Wales, Australia. Hydrological sciences journal, 62(13), pp.2160-2174.

15. Hanif M, Khan AH, Adnan S (2013) Latitudinal precipitation characteristics and trends in Pakistan. J Hydrol 492:266272

16. Hussain MS, Lee S (2013) The regional and the seasonal variability of extreme precipitation trends in Pakistan. Asia-Pac J Atmos Sci 49: 421-441

17. Hussain MS, Lee S (2014) Long-term variability and changes of the precipitation regime in Pakistan. Asia-Pac J Atmos Sci 50:271-282

18. Iqbal, M.F. and Athar, H., 2017. Variability, trends, and teleconnections of observed precipitation over Pakistan. Theoretical and applied climatology, 134(1-2), pp.613-632.

19. IPCC (Intergovernmental Panel on Climate Change (2013). Climate change 2013: the physical science basis. In Contribution of Working Group, I to the Fifth Assessment Report of the Intergovernmental Panel on Climate Change, Stocker TF, Qin D, Plattner G-K, Tignor M, Allen SK, Boschung J, Nauels A, Xia Y, Bex V, Midgley PM (eds). Cambridge University Press: Cambridge, UK; 1535 pp.

20. IPCC (Intergovernmental Panel on Climate Change), 2014. Climate Change 2014 Synthesis Report Summary for Policymakers, AR4.

21. Kreft S, Eckstein D (2013) Who suffers most from extreme weather events? Weather-related loss events in 2012 and 1993 to 2012. Germanwatch, Bonn

22. Krichak, S.O., Breitgand, J.S., Gualdi, S. and Feldstein, S.B., 2014. Teleconnection-extreme precipitation relationships over the Mediterranean region. Theoretical and applied climatology, 117(3-4), pp.679-692.

23. Krishnamurthy, L. and Krishnamurthy, V., 2017. Indian monsoon's relation with the decadal part of PDO in observations and NCAR CCSM4. International Journal of Climatology, 37(4), pp.1824-1833.

24. Liess, S. and Geller, M.A., 2012. On the relationship between QBO and distribution of tropical deep convection. Journal of Geophysical Research: Atmospheres, 117(D3). 
25. Libiseller, C. and Grimvall, A., 2002. Performance of partial Mann-Kendall tests for trend detection in the presence of covariates. Environmetrics: The official journal of the International Environmetrics Society, 13(1), pp.71-84.

26. Liu, Chao \& Jarochowska, Emilia \& Du, Yuansheng \& Vachard, Daniel \& Munnecke, Axel. (2015). Liu et al. 2015

27. Liu D., Guo S., Chen X., and Shao Q., “Analysis of trends of annual and seasonal precipitation from 1956 to 2000 in Guangdong Province, China,” Hydrological Sciences Journal, vol. 57, no. 2, pp. 358-369, 2012.

28. Lucas-Picher, P., Christensen, J.H., Saeed, F., Kumar, P., Asharaf, S., Ahrens, B., Wiltshire, A.J., Jacob, D. and Hagemann, S., 2011. Can regional climate models represent the Indian monsoon? Journal of Hydrometeorology, 12(5), pp.849-868.

29. Machiwal, D. and Jha, M.K., 2009. Time series analysis of hydrologic data for water resources planning and management: a review. Journal of Hydrology and Hydromechanics, 54(3), pp.237-257.

30. Maida Z, Ghulam R (2011) Frequency of extreme temperature and pre- cipitation events in Pakistan 1965-2009. Sci Int 23:313-319

31. Mann, H.B., (1945) nonparametric tests against trend. Econometrica 13: 245-259.

32. Naz, F., Dars, G.H., Ansari, K., Jamro, S. and Krakauer, N.Y., 2020. Drought Trends in Balochistan. Water, 12(2), p.470

33. Niranjan Kumar, K. and Ouarda, T.B.M.J., 2014. Precipitation variability over UAE and global SST teleconnections. Journal of Geophysical Research: Atmospheres, 119(17), pp.10-313

34. Rashid, A., 2004. Impact of El-Nino on summer monsoon rainfall of Pakistan. Pakistan Journal of Meteorology, 1(2).

35. Salma S, Rehman S, Shah MA (2012) Rainfall trends in different climate zones of Pakistan. Pak J Meteorol 9:37-47

36. Scarpati O. E., Spescha L. B., Lay J. A. F., and Capriolo A. D., (2011) "Soil water surplus in salado river basin and its variability during the last forty years (buenos aires province, argentina)," Water, vol. 3, pp. 132-145.

37. Shahid, A.; Zahid, H.; Qureshi, A.S.; Rashida, M.; Mohammad, S. Drought mitigation in Pakistan: Current status and options for future strategies. IWMI Work. Paper 2004, 85. Available online: http://www.iwmi.cgiar.org/Publications/ Working Papers /working/WOR85.pdf

38. Van Oldenborgh, G.J., Philip, S.Y. and Collins, M., (2005). El Niño in a changing climate: a multi-model study. Ocean Science, 1(2), pp.81-95.

39. Vermeer, M. and S. Rahmstorf, 2009: Global sea level linked to global temperature. Proceedings of the National Academy of Science of the USA, 106, 21527-21532.

40. Viterbo F, Hardenberg JV, Provenzale A, Molini L, Parodi A, Provenzale A, Sy OO, Tanelli S (2016) High-resolution simulations of the 2010 Pakistan flood event: sensitivity to parameterizations and initializa- tion time. J Hydrometeorol 17:1147-1167

41. Verworn H., Krämer S., Becker M., and Pfister A., (2008) "The impact of climate change on rainfall runoff statistics in the Emscher-Lippe region," in Proceedings of the 11th International Conference on Urban Drainage, pp. 1-10, Edinburgh, UK.

42. M. Wallace, John \& S. Gutzler, David. (1981). Teleconnections in the Geopotential Height Field during the Northern Hemisphere Winter. Mon. Wea. Rev.. 109. 784-812. 10.1175/1520-0493(1981)109<0784:TITGHF>2.0.CO;2.

43. Wang S, Davies RE, Huang W, Gillies RR (2011) Pakistan's two-stage monsoon and links with the recent climate change. J Geophys Res 116:D16114

44. Wu, Zeng-Yuan \& Monro, Alex \& Milne, Richard \& Wang, Hong \& Yi, Tingshuang \& Liu, Jie \& Li, De-Zhu. (2013). wu-2013.

45. Webster PJ, Toma VE, Kim H-M (2011) Were the 2010 Pakistan floods predictable? Geophys Res Lett 38:L04806 
46. Yang X., Xu L., Liu K., Li C., Hu J., and Xia X., (2012) “Trends in temperature and precipitation in the zhangweinan river basin during the last 53 years," Procedia Environmental Sciences, vol. 13, pp. 1966-1974.

47. Yadav, R.K., Rupa Kumar, K. and Rajeevan, M., 2009. Increasing influence of ENSO and decreasing influence of $\mathrm{AO} / \mathrm{NAO}$ in the recent decades over northwest India winter precipitation. Journal of Geophysical Research: Atmospheres, 114(D12). 